\title{
Clinical Relevance of Biomarkers of Oxidative Stress
}

\author{
Jeroen Frijhoff, ${ }^{1}$ Paul G. Winyard, ${ }^{2}$ Neven Zarkovic, ${ }^{3}$ Sean S. Davies, ${ }^{4,5}$ Roland Stocker, ${ }^{6,7}$ \\ David Cheng, ${ }^{6}$ Annie R. Knight, ${ }^{2}$ Emma Louise Taylor, ${ }^{2}$ Jeannette Oettrich, ${ }^{1}$ Tatjana Ruskovska, \\ Ana Cipak Gasparovic, ${ }^{3}$ Antonio Cuadrado, ${ }^{9-12}$ Daniela Weber, ${ }^{13}$ Henrik Enghusen Poulsen, ${ }^{14,15}$ \\ Tilman Grune, ${ }^{13}$ Harald H.H.W. Schmidt, and Pietro Ghezzi ${ }^{16}$
}

\begin{abstract}
Significance: Oxidative stress is considered to be an important component of various diseases. A vast number of methods have been developed and used in virtually all diseases to measure the extent and nature of oxidative stress, ranging from oxidation of DNA to proteins, lipids, and free amino acids. Recent Advances: An increased understanding of the biology behind diseases and redox biology has led to more specific and sensitive tools to measure oxidative stress markers, which are very diverse and sometimes very low in abundance. Critical Issues: The literature is very heterogeneous. It is often difficult to draw general conclusions on the significance of oxidative stress biomarkers, as only in a limited proportion of diseases have a range of different biomarkers been used, and different biomarkers have been used to study different diseases. In addition, biomarkers are often measured using nonspecific methods, while specific methodologies are often too sophisticated or laborious for routine clinical use. Future Directions: Several markers of oxidative stress still represent a viable biomarker opportunity for clinical use. However, positive findings with currently used biomarkers still need to be validated in larger sample sizes and compared with current clinical standards to establish them as clinical diagnostics. It is important to realize that oxidative stress is a nuanced phenomenon that is difficult to characterize, and one biomarker is not necessarily better than others. The vast diversity in oxidative stress between diseases and conditions has to be taken into account when selecting the most appropriate biomarker. Antioxid. Redox Signal. 23, 1144-1170.
\end{abstract}

\footnotetext{
${ }^{1}$ Faculty of Health, Medicine and Life Sciences, Cardiovascular Research Institute Maastricht (CARIM), Maastricht University, Maastricht, the Netherlands.

${ }^{2}$ University of Exeter Medical School, Exeter, United Kingdom.

${ }^{3}$ LabOS, Rudjer Boskovic Institute, Zagreb, Croatia.

${ }^{4}$ Department of Medicine, Vanderbilt University, Nashville, Tennessee.

${ }^{5}$ Division of Clinical Pharmacology, Department of Pharmacology, Vanderbilt University, Nashville, Tennessee.

${ }^{6}$ Vascular Biology Division, Victor Chang Cardiac Research Institute, Darlinghurst, New South Wales, Australia.

${ }^{7}$ School of Medical Sciences, University of New South Wales, Sydney, New South Wales, Australia.

${ }^{8}$ Faculty of Medical Sciences, Goce Delcev University, Stip, Macedonia.

${ }^{9}$ Centro de Investigación Biomedica en Red sobre Enfermedades Neurodegenerativas (CIBERNED), ISCIII, Madrid, Spain.

${ }^{10}$ Instituto de Investigaciones Biomedicas "Alberto Sols" UAM-CSIC, Madrid, Spain.

${ }^{11}$ Instituto de Investigacion Sanitaria La Paz (IdiPaz), Madrid, Spain.

${ }^{12}$ Department of Biochemistry, Faculty of Medicine, Autonomous University of Madrid, Madrid, Spain.

${ }^{13}$ Department of Molecular Toxicology, German Institute of Human Nutrition (DIfE), Nuthetal, Germany.

${ }^{14}$ Faculty of Health Science, University of Copenhagen, Copenhagen, Denmark.

${ }^{15}$ Bispebjerg-Frederiksberg Hospital, Copenhagen, Denmark.

${ }^{16}$ Brighton and Sussex Medical School, Brighton, United Kingdom.

(C) Jeroen Frijhoff et al. 2015; Published by Mary Ann Liebert, Inc. This Open Access article is distributed under the terms of the Creative Commons Attribution Noncommercial License (http://creativecommons.org/licenses/by-nc/4.0/) which permits any noncommercial use, distribution, and reproduction in any medium, provided the original author(s) and the source are credited.
} 


\section{Introduction}

$\mathbf{R}$ EDOX SIGNALING OPERATES through discrete, reversible, and site-specific modifications of certain proteins (184). Reversible modifications of cysteine residues include S-nitrosylation/S-nitrosation, sulfenylation, disulfide bonds, and S-glutathionylation $(83,87)$. These redox signalinginduced changes, performed by reactive oxygen and nitrogen species (ROS and RNS), target protein activities within complex networks of kinases, phosphatases, ion channels, and apoptotic cascades and can cause changes in transcriptional activity $(50,53,74,83)$. Oxidative stress, characterized by an imbalance between oxidants and antioxidants in favor of oxidants, leads to disruption of redox signaling and physiological function $(157,158)$. Oxidative stress might also lead to irreversible chemical modifications $(152,164)$. One of the weaknesses of the underpinning science is the lack of validated oxidative stress biomarkers. Analytical issues surrounding the validation of oxidative stress biomarkers have received substantial attention recently $(33,100)$. However, there remains increasing interest in exploring their potential clinical applications. While the current review will touch upon analytical issues, its focus will be on synthesizing the status - and future potential—of oxidative stress biomarkers as clinical diagnostics from available literature.

The World Health Organization has defined a biomarker as any substance, structure, or process that can be measured in the body or its products and influence or predict the incidence of outcome or disease (192). Markers of oxidative stress often fulfill the first part of the criteria (i.e., they can be measured) and many studies suggest oxidative stress can influence the disease, but to be a clinically relevant biomarker, some additional issues must also be addressed. In summary, a clinically useful biomarker must be able to meet one of the following criteria: (i) show specificity for a certain disease (diagnostic), (ii) have prognostic value, and (iii) correlate with disease activity. This then allows treatment efficacy to be assessed. To be clinically useful, a biomarker must also be reasonably stable, present in an easily accessible tissue, and cost-effective to measure reproducibly on a large scale.

An increasing number of studies are published on markers of oxidative stress in a whole range of human diseases (Fig. 1). While a plethora of markers and methods are used, many of these do not correlate well with each other, do not reflect a state of oxidative stress, or are not specific. In this study, we critically review the current state of oxidative stress biomarkers that are used to assess the redox state of the body or specific tissues and cells in health and disease, with a focus on those that can be realistically applied to the clinic (Fig. 2). This approach excludes by definition several commonly used preclinical and in vitro methods. Visualization of biomarkers measured in various diseases by cluster analysis (Fig. 3) shows that the majority of studies have used ROS-induced modifications as markers of oxidative stress, which will be discussed first. We then focus on biomarkers assessing two important components whose deregulation can result in oxidative stress, ROS generation, and antioxidant defense. We conclude with two functional markers that are downstream of oxidative stress. From a clinical perspective, what matters is which marker is predictive with respect to risk and therapeutic outcome.
A
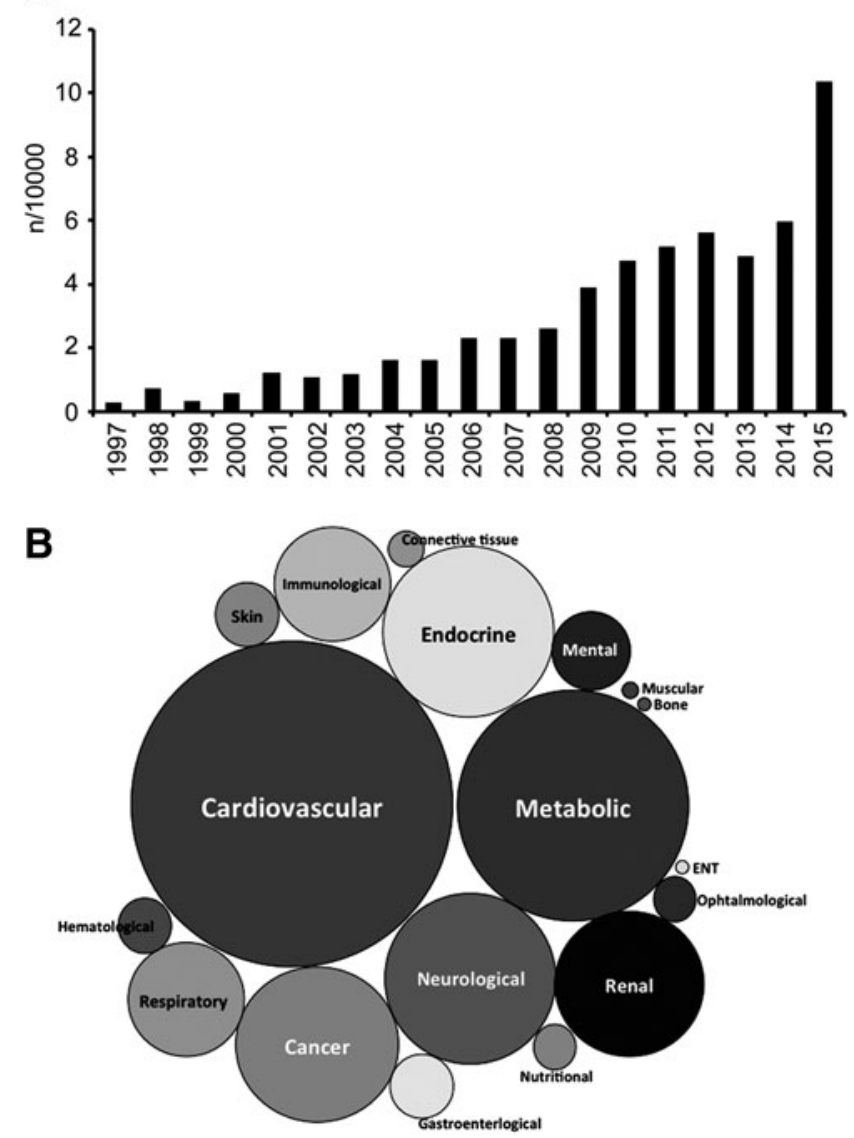

FIG. 1. Publications on oxidative stress biomarkers in different diseases. Searches were performed using oxidative stress biomarkers patients and the specific disease MeSH term using Web of Science. (A) Indicates the number of hits of all diseases combined per 10,000, normalized to a search with patients and the diseases in question. (B) Shows the number of hits per disease, which is proportional to the circle size, for the years 2005-2015.

\section{ROS-Induced Modifications}

This category includes biomarkers measuring evidence of direct chemical impact of ROS in biological systems. One of the ROS subsets is also described as RNS, for example, ${ }^{\bullet} \mathrm{NO}$ and $\mathrm{ONOO}^{-}$. Besides causing post-translational modifications of proteins, these species may also cause nitrative stress and RNS-induced modifications, such as tyrosine nitration.

\section{Protein carbonyls and advanced glycation end products}

Protein carbonyls are formed through oxidative cleavage of protein backbones. Oxidative deamination of lysine and glutamic acid also results in protein carbonyls (34). Since carbonyls can arise from different mechanisms, their concentration is commonly higher than that of other biomarkers (40).

Carbonyl groups may also be introduced by binding of aldehydic lipid oxidation products to lysine, cysteine, and histidine residues - a reaction termed Michael additionresulting in advanced lipoxidation end products. Reactions 


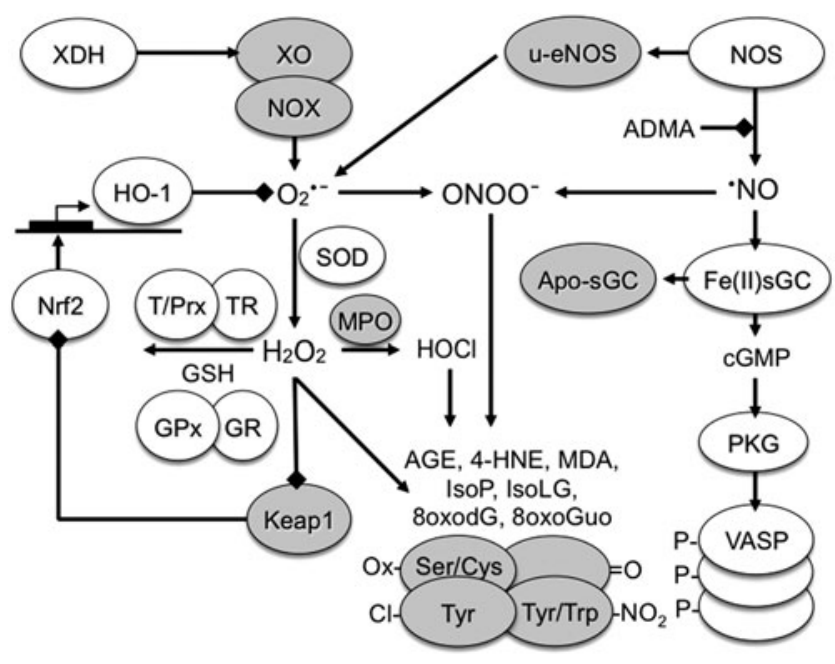

FIG. 2. Redox pathways associated with putative biomarkers of oxidative stress. The processes that lead to oxidative modifications of proteins, lipids, and nucleotides are highly complex. Enzymes, such as XO, NOX, and NOS, can produce ROS and RNS. These ROS can furthermore serve as substrates for other enzymes to generate additional types of ROS, such as the generation of $\mathrm{HOCl}$ from $\mathrm{H}_{2} \mathrm{O}_{2}$ by MPO. Cellular systems and enzymes, including the GSH and thioredoxin system, together with peroxiredoxins (T/Prx), counterbalance the production of ROS. In addition, increased levels of ROS activate Nrf2 to transcribe genes that are involved in counteracting these ROS. Oxidative stress affects cGMP signaling through its effects on nitric oxide ( $\left.{ }^{\circ} \mathrm{NO}\right)$ production, scavenging, and on the ${ }^{\circ} \mathrm{NO}$ receptor sGC. cGMP, cyclic guanosine monophosphate; $\mathrm{GSH}$, glutathione; $\mathrm{H}_{2} \mathrm{O}_{2}$, hydrogen peroxide; $\mathrm{HOCl}$, hypochlorous acid; MPO, myeloperoxidase; NOS, nitric oxide synthase; NOX, NADPH oxidase; RNS, reactive nitrogen species; ROS, reactive oxygen species; sGC, soluble guanylate cyclase; $\mathrm{XO}$, xanthine oxidase.

between lysine and arginine residues and carbohydrates-a reaction called glycoxidation-result in advanced glycation end products (AGEs).

AGEs are a group of heterogeneous molecules that arise from the nonenzymatic reaction of reducing sugars with amino groups of lipids, DNA, and especially long-lived proteins. This process occurs during normal metabolism, but is even more pronounced under hyperglycemic, hyperlipidemic, and oxidative stress conditions.

The glycation reaction can be accompanied by an oxidation leading to glycoxidation products. Carboxymethyl valine and pentosidine are among the most prominent AGEs resulting from glycoxidation. Glyoxal, generated from metalcatalyzed oxidation of polyunsaturated fatty acids (PUFAs), forms adducts with lysine (resulting in carboxymethyl lysine [CML]), an advanced lipoxidation product (55). About $90 \%$ of CML and pentosidine in blood are bound to proteins (116). Due to their relationship to sugars, AGEs have been linked to diabetes mellitus and other diseases, such as obesity (20), atherosclerosis, renal failure (193), and Alzheimer's disease (172). Due to the different possible formation mechanisms and heterogeneity, numerous glycation products exist, of which only some have been characterized so far.

Protein carbonyls (i.e., having aldehyde and ketone moieties) are usually detected after derivatization with 2,4-dinitrophenylhydrazine (DNP). The resulting carbonyl2,4-dinitrophenylhydrazine adduct (101) can be detected spectrophotometrically or by specific anti-DNP antibodies with ELISA (24), Western blot (91), immunohisto- and cytochemistry, or by high-performance liquid chromatography (HPLC). The results of the ELISA correlate well with the colorimetric assay (24), whereby the ELISA is more convenient to analyze a larger number of samples within one run and requires significantly less sample volume. Concerning clinical settings, the only methods that seem to be applicable are ELISA (kits are available) and HPLC as they enable high throughput, involve internal/external standards, and comparison of samples under constant conditions.

A number of methods have been reported to measure AGEs based on the use of antibodies for immunohistochemistry, immunoblot, and commercial ELISA, as well as special AGE readers that utilize the autofluorescence properties of AGEs in human skin to assess AGE concentrations. Spectrofluorometry can be applied to diluted plasma or serum samples and a fructosamine assay to detect ketoamines (9). HPLC allows the identification and measurement of specific AGEs such as pentosidine (169) and CML (52). Creatinine glycation products can be measured with stable isotope dilution analysis and liquid chromatography (LC)-MS/MS (97). Due to the structural heterogeneity of AGEs, there is no method that can be especially recommended for measuring specific AGEs in a clinical setting. Noninvasive spectrographic autofluorescence readers can be applied in a clinical setting; however, this should be standardized in terms of using the average of three readings, the same body region, avoiding surrounding light and skin areas with tattoos. Elevated skin autofluorescence has been demonstrated in diabetes, kidney disease, and in patients with arterial stiffness.

In humans, elevated protein carbonyl levels have been reported in numerous conditions, including aging (61), neurodegenerative diseases (62), obesity, diabetes mellitus, age-related macular degeneration (174), human immunodeficiency virus (HIV), anemia, sickle cell disease, newborn bronchopulmonary dysplasia, and hepatocellular carcinoma (Table 1).

Protein carbonyls increase with age in healthy women and men $(61,122)$. With age, AGEs accumulate in the skin and correlate with the glucose exposure dose in patients on peritoneal dialysis (25). In diabetes, ROS are generated through several pathways, and elevated AGE concentrations have been reported. Ischemia/reperfusion is clearly associated with oxidative stress. Following coronary surgery in the reperfused human heart, a 2-3-fold increase in protein carbonyls, as measured by ELISA, was observed in plasma isolated from the venous coronary sinus (130). Protein carbonyls remained increased in blood for up to $18 \mathrm{~h}$ and therefore meet one important criterion for being a marker of oxidative stress, which is their stability.

Most methods detect protein carbonyls after derivatization and therefore do not provide a direct measure of these oxidative modifications. While commercial ELISA kits for AGE measurement provide ease of use, many of these do not specify the antibody used, which is just described as polyclonal anti-AGE antibody. This may lead to differences between commercial kits. Nevertheless, protein carbonyls and AGEs have been among the most successful markers of 
FIG. 3. Cluster analysis of ROS biomarkers in disease. Different diseases were clustered according to described ROS biomarkers in Refs. (33, $100,181)$ and studies described in this review. Some disease conditions cluster as might be expected, such as ischemia/reperfusion and heart failure, and amyotrophic lateral sclerosis and multiple sclerosis. A comprehensive analysis of ROS markers and pattern analysis in diseases might uncover common disease mechanisms or new measures of disease progression or treatment outcome. Cluster analysis was performed using Genesis software (https:// genome.tugraz.at/genesisclient/ genesisclient_description.shtml) as described in Mengozzi et al. (111).

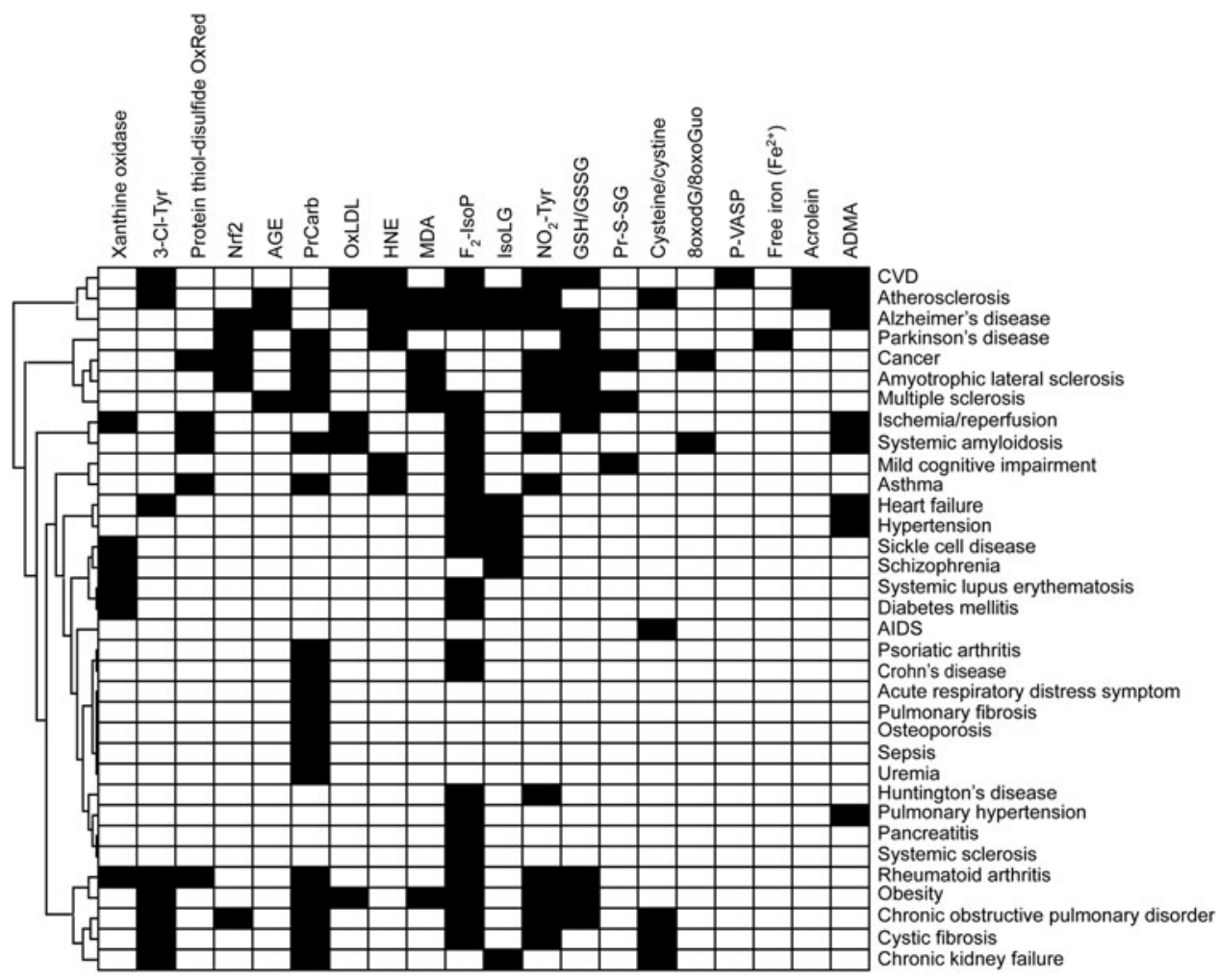

oxidative stress and are associated with disease state and treatment in multiple diseases (Tables 1 and 2).

\section{Oxidized low-density lipoprotein}

The measurement of oxidized low-density lipoprotein (oxLDL) as a biomarker of oxidative stress has its origin in the oxidative modification hypothesis of atherosclerosis (165). However, oxLDL does not chemically define a specific form of modified LDL, molecule, or family of molecules (166). As the potential of oxLDL as a biomarker for cardiovascular disease (CVD) has been the subject of previous reviews $(175,177)$, we will critically assess the clinical utility of oxLDL as a biomarker.

Table 1. Selected Clinical Studies of Protein Carbonyl Levels in Different Diseases

\begin{tabular}{|c|c|c|c|c|}
\hline Disease/Condition & Sample & Method & Observation & Reference $^{\mathrm{a}}$ \\
\hline $\begin{array}{l}\text { HIV-associated cognitive } \\
\text { impairment }\end{array}$ & $\begin{array}{l}\text { Cerebrospinal } \\
\text { fluid }\end{array}$ & $\begin{array}{l}\text { Commercial } \\
\text { Oxyblot kit }\end{array}$ & $\begin{array}{l}\text { No significant differences in PC } \\
\text { between treatment and placebo } \\
\text { after selegiline transdermal } \\
\text { system versus placebo. }\end{array}$ & $(85)$ \\
\hline $\begin{array}{l}\text { Chronic heart failure, } \\
\text { secondary to ischemic or } \\
\text { idiopathic cardiomyopathy }\end{array}$ & Plasma & Spectrophotometry & $\begin{array}{l}\text { Significantly decreased PC after } \\
\text { treatment with darbepoetin alfa } \\
\text { (placebo: no effect). }\end{array}$ & $(75)$ \\
\hline Sickle cell disease & Plasma & Spectrophotometry & $\begin{array}{l}\alpha \text {-Lipoic acid treatment in healthy } \\
\text { subjects reduced PC }(P<0.05) \\
\text { no effect in sickle cell disease. }\end{array}$ & (64) \\
\hline $\begin{array}{l}\text { Newborns (low birth weight), } \\
\text { without bronchopulmonary } \\
\text { dysplasia }\end{array}$ & Plasma & ELISA & $\begin{array}{l}\text { No significant difference in PC } \\
\text { between newborns and controls } \\
\text { treated with inhaled nitric oxide. } \\
\text { Positive correlation between PC } \\
\text { and respiratory severity score. }\end{array}$ & (8) \\
\hline Hepatocellular carcinoma & Plasma & ELISA & $\begin{array}{l}\text { Significantly higher PC in subjects } \\
\text { with hepatocellular carcinoma } \\
\text { compared with subjects with or } \\
\text { without Hepatitis B virus. }\end{array}$ & (61) \\
\hline
\end{tabular}

${ }^{a}$ References are provided as supplementary material (Supplementary Data are available online at www.liebertpub.com/ars). HIV, human immunodeficiency virus; PC, protein carbonyl. 
Table 2. Selected Clinical Studies of AGE Levels in Different Diseases

\begin{tabular}{|c|c|c|c|c|}
\hline $\begin{array}{l}\text { Disease/ } \\
\text { Condition }\end{array}$ & Sample & Method & Observation & Reference $^{\mathrm{a}}$ \\
\hline $\mathrm{T} 2 \mathrm{D}$ & Urine, plasma & $\begin{array}{l}\text { Stable isotope dilution } \\
\text { analysis and LC-MS/MS }\end{array}$ & $\begin{array}{l}\text { Higher basal level in } \\
\text { diabetics. }\end{array}$ & (57) \\
\hline $\mathrm{T} 2 \mathrm{D}$ & Skin & SAF & $\begin{array}{l}\text { Short-term therapy with } \\
\text { benfotiamine did not } \\
\text { significantly influence } \\
\text { SAF. }\end{array}$ & (97) \\
\hline T1D, T2D & Skin & SAF & $\begin{array}{l}\text { Comparable SAF between } \\
\text { children with type I } \\
\text { diabetes and nondiabetic } \\
\text { adults, indicating } \\
\text { chronological aging of the } \\
\text { skin. }\end{array}$ & (88a) \\
\hline Diabetes & $\begin{array}{l}\text { EDTA plasma, } \\
\text { carotid plaque } \\
\text { tissue }\end{array}$ & $\begin{array}{l}\text { ELISA, } \\
\text { immunohistochemistry }\end{array}$ & $\begin{array}{l}\text { Plasma sRAGE } \\
\text { concentrations higher in } \\
\text { symptomatic patients. }\end{array}$ & (10) \\
\hline $\begin{array}{l}\text { Acute coronary } \\
\text { syndrome }\end{array}$ & Serum & Competitive ELISA & $\begin{array}{l}\text { AGE decreased significantly } \\
\text { with statin treatment, AGE } \\
\text { levels correlated with } \\
\text { plaque progression } \\
\text { independently of diabetes. }\end{array}$ & (43) \\
\hline $\begin{array}{l}\text { Chronic kidney } \\
\text { disease }\end{array}$ & Skin & SAF (AGE Reader) & $\begin{array}{l}\text { Significantly higher SAF in } \\
\text { children with kidney } \\
\text { disease in comparison with } \\
\text { controls; positive linear } \\
\text { correlation between SAF } \\
\text { and dialysis treatment } \\
\text { duration. }\end{array}$ & (62) \\
\hline Dialysis & Skin & SAF (AGE Reader) & $\begin{array}{l}\text { Accumulation of tissue AGEs } \\
\text { is correlated with glucose } \\
\text { exposure dose and } \\
\text { independently associated } \\
\text { with cardiovascular } \\
\text { morbidity in patients on } \\
\text { peritoneal dialysis. }\end{array}$ & (50) \\
\hline $\begin{array}{l}\text { Pancreatic cancer } \\
\text { (EPIC study) }\end{array}$ & Serum & ELISA & $\begin{array}{l}\text { Elevated CML was associated } \\
\text { with reduced pancreatic } \\
\text { cancer risk (the association } \\
\text { disappeared after } \\
\text { adjustment for HbA1c, } \\
\text { BMI, smoking status, and } \\
\text { endogenous secreted } \\
\text { RAGE). }\end{array}$ & (45) \\
\hline $\begin{array}{l}\text { Pancreatic cancer } \\
\text { (ATBC study) }\end{array}$ & Serum & AGE CML-ELISA & $\begin{array}{l}\text { Higher levels of CML-AGE } \\
\text { were not associated with a } \\
\text { higher risk of pancreatic } \\
\text { cancer. }\end{array}$ & (51) \\
\hline PCOS & Serum & Competitive AGE-ELISA & $\begin{array}{l}\text { AGEs are elevated in women } \\
\text { with PCOS and strongly } \\
\text { positively correlated with } \\
\text { androgen levels in women } \\
\text { with PCOS. }\end{array}$ & (37) \\
\hline
\end{tabular}

${ }^{a}$ References are provided as supplementary material.

AGE, advanced glycation end product; BMI, body-mass index; CML, carboxymethyl lysine; LC, liquid chromatography; MS, mass spectrometry; PCOS, polycystic ovary syndrome; SAF, skin autofluorescence; sRAGE, secreted receptor for AGE; T1D, type 1 diabetes; T2D, type 2 diabetes. 
OxLDL is most commonly measured in plasma or isolated LDL by immunological methods using one of three different antibodies that appear most frequently in the literature: 4E6, DLH3, and E06. The monoclonal antibody, 4E6, binds to aldehyde-modified lysine residues on LDL (73) and is the basis of a commercial method. The monoclonal antibodies, DLH3 and E06, recognize oxidized phosphatidylcholine (82) and phosphorylcholine containing short oxidized or nonoxidized side chains, respectively. Plasma oxLDL has been consistently found elevated in patients with CVD, independent of the assay used. However, conflicting results have been reported in studies on the association of oxLDL with atherosclerosis severity and the usefulness of oxLDL for CVD prediction. Contrasting results, depending on the assay, have been reported for plasma oxLDL following pharmacological intervention with statins $(175,177)$. In addition to CVD, plasma oxLDLs are increased in patients with insulin resistance, diabetes, and obesity (175).

A general limitation of the single most commonly used 4E6-based assay is that native LDL is also detected. As a result, the concentrations of oxLDLs determined closely reflect the concentrations of LDL cholesterol, and the predictive value of the assays is dependent on the levels of apoB (194). This casts serious doubt over the usefulness of oxLDL as a measure of oxidative stress and its clinical utility to predict cardiovascular and associated diseases above that of LDL cholesterol. Another general problem is that results obtained with different antibodies/methods cannot be compared and often do not correlate with each other, which is inconsistent with oxLDL being a quantitative measure of oxidative stress or representing a meaningful tool to predict CVD. The DLH13-based method was developed for isolated LDL, which limits its clinical utility because LDL isolation is time-consuming and isolated LDL is prone to ex vivo oxidation when stored at $4^{\circ} \mathrm{C}$ or after coating on plates. An extension of this assay to plasma has been developed commercially, but its utility is questionable because plasma and isolated LDL data do not match (81). A major problem with E06-based methods to determine oxLDL is that contrary to the common notion $(175,177)$, the monoclonal antibody is not specific for oxidized (phospho)lipids (51) and most of the recognized antigens in plasma reside in lipoproteins other than LDLs (178).

Given the limitations summarized above, oxLDL is unlikely a specific measure of oxidative stress. This is consistent with the majority of human plasma $\mathrm{F}_{2}$-isoprostanes (135a) and cholesterylester hydroperoxides (16) being associated with high-density lipoproteins (HDLs) rather than LDLs.

\section{Lipid oxidation products}

PUFAs, in particular linoleic and arachidonic acid (AA), are important targets of lipid peroxidation. Reaction of ROS, in particular hydroxyl and peroxyl radicals, with bisallylic hydrogen of PUFAs initiates the autocatalytic chain reaction of lipid peroxidation (Reactions 1-3) during which lipid peroxyl radicals act as chain-carrying radicals and lipid hydroperoxides are formed as the primary end products.
Initiation $\mathrm{LH}+\mathrm{R}^{\bullet} \rightarrow \mathrm{L}^{\bullet}+\mathrm{RH}$

Propagation $\mathrm{L}^{\bullet}+\mathrm{O}_{2} \rightarrow \mathrm{LOO}^{\bullet}$

$$
\mathrm{LOO}^{\bullet}+\mathrm{LH} \rightarrow \mathrm{LOOH}+\mathrm{L}^{\bullet}
$$

Termination $\mathrm{LOO}^{\bullet}+\alpha-\mathrm{TOH} \rightarrow \mathrm{LOOH}+\alpha-\mathrm{TO}^{\bullet}$

$$
\mathrm{LOO}^{\bullet}+\alpha-\mathrm{TO}^{\bullet} \rightarrow \mathrm{NRP}
$$

The chain reaction of lipid peroxidation can be terminated by tocopherols, such as $\alpha$-tocopherol $(\alpha$-TOH), via reaction with the chain-propagating lipid peroxyl radical $\left(\mathrm{LOO}^{\bullet}\right.$ ) (Reaction $\left.4 \mathrm{a}\right)$. The resulting $\alpha$-tocopherol radical $\left(\alpha-\mathrm{TO}^{\bullet}\right)$ can be reduced back to $\alpha$-TOH by certain reducing agents (e.g., ascorbate) (not shown) or react with a second molecule of $\mathrm{LOO}^{\bullet}$ to form a nonradical product (NRP) (Reaction 4b).

$$
\begin{aligned}
& \mathrm{LOOH}+\mathrm{Fe}^{3+} \rightarrow \mathrm{LOO}^{\bullet}+\mathrm{Fe}^{2+}+\mathrm{H}^{+} \\
& \mathrm{LOOH}+\mathrm{Fe}^{2+} \rightarrow \mathrm{LO}^{\bullet}+\mathrm{Fe}^{3+}+{ }^{\bullet} \mathrm{OH}
\end{aligned}
$$

Degradation $\mathrm{LOO}^{\bullet} \rightarrow \rightarrow \rightarrow$ reactive aldehydes

$$
\text { (e.g., MDA, HNE, acrolein) }
$$

In the presence of transition metals, lipid hydroperoxides (LOOHs) give rise to $\mathrm{LOO}^{\bullet}$ (Reaction 5) or lipid alkoxyl radicals $\left(\mathrm{LO}^{\bullet}\right)$ (Reaction 6) that are further cyclized and/or degraded into several different reactive aldehydes (Reaction 7) that participate in various biological processes and signal transduction pathways (200). Depending on the type of PUFAs undergoing lipid oxidation, these include trans-4-hydroxy-2nonenal (4-HNE), malondialdehyde (MDA), and others. Aldehydes derived from lipids are very reactive and therefore readily react with proteins to form Michael adducts, often denoted as advanced lipoxidation end products (49).

Isoprostanes (IsoPs) are formed during free radicalcatalyzed oxidation of AA (119). Radical-mediated oxidation of AA occurs independently of whether it is esterified (as in phospholipids, triacylglycerols, or cholesterylesters). The types of IsoPs that will be formed and in what ratio depend on oxygen tension and glutathione concentration (120).

\section{4-HNE and MDA}

Different methods are available for the detection of both MDA and 4-HNE. Antibodies against MDA and 4-HNE bound to different amino acids have been developed $(179,186)$ and used in qualitative and semiquantitative immunocyto- and immunohistochemistry, where their presence and relative abundance are detected in cells and tissues in parallel with evaluation of morphological changes (126). Since Spiteller (163) reviewed the involvement of lipid peroxidation in a variety of chronic diseases, lipid oxidation end products emerged as oxidative stress markers, with 4-HNE and MDA being among the most investigated $(126,200)$ (Table 3). 


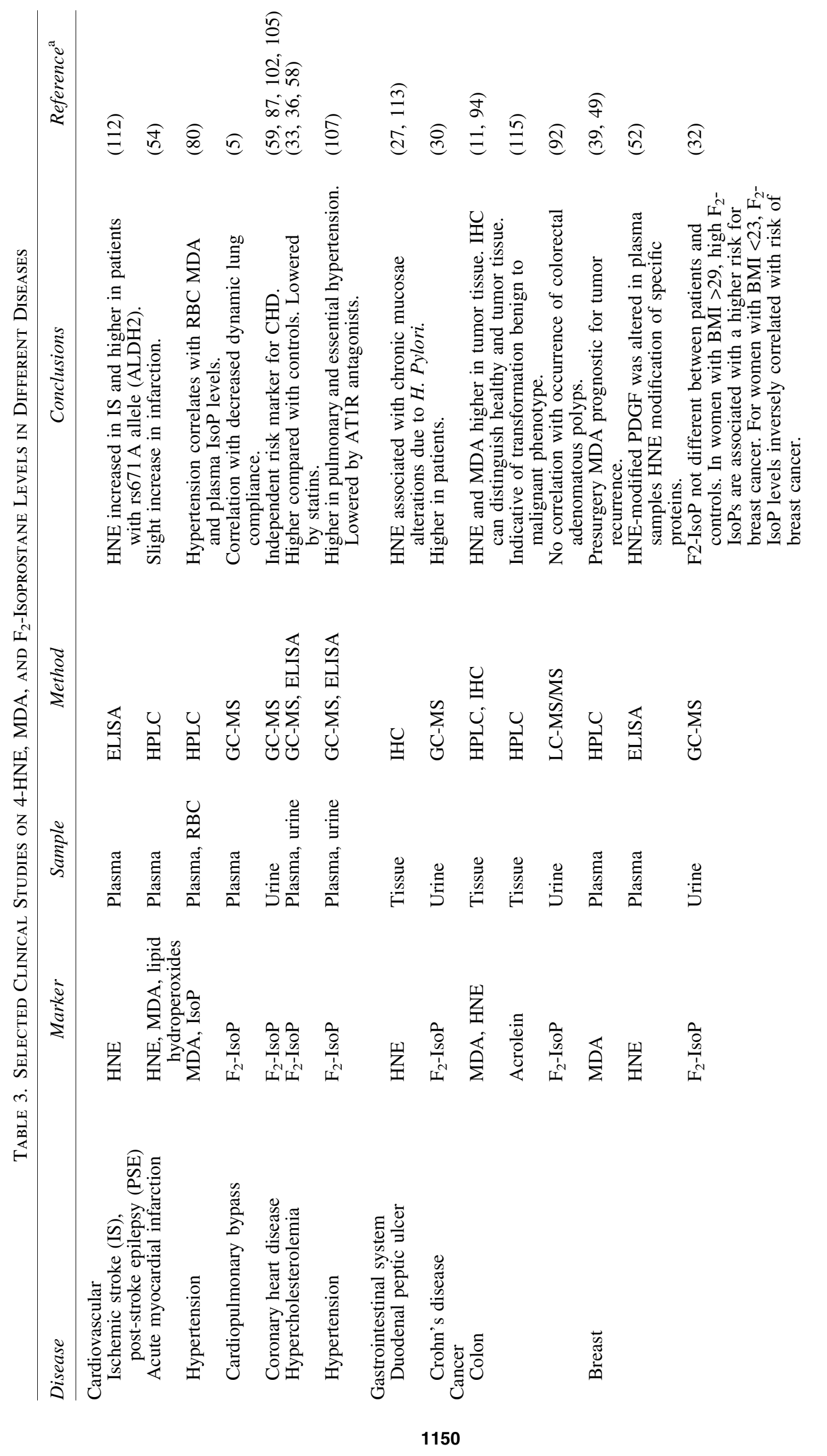




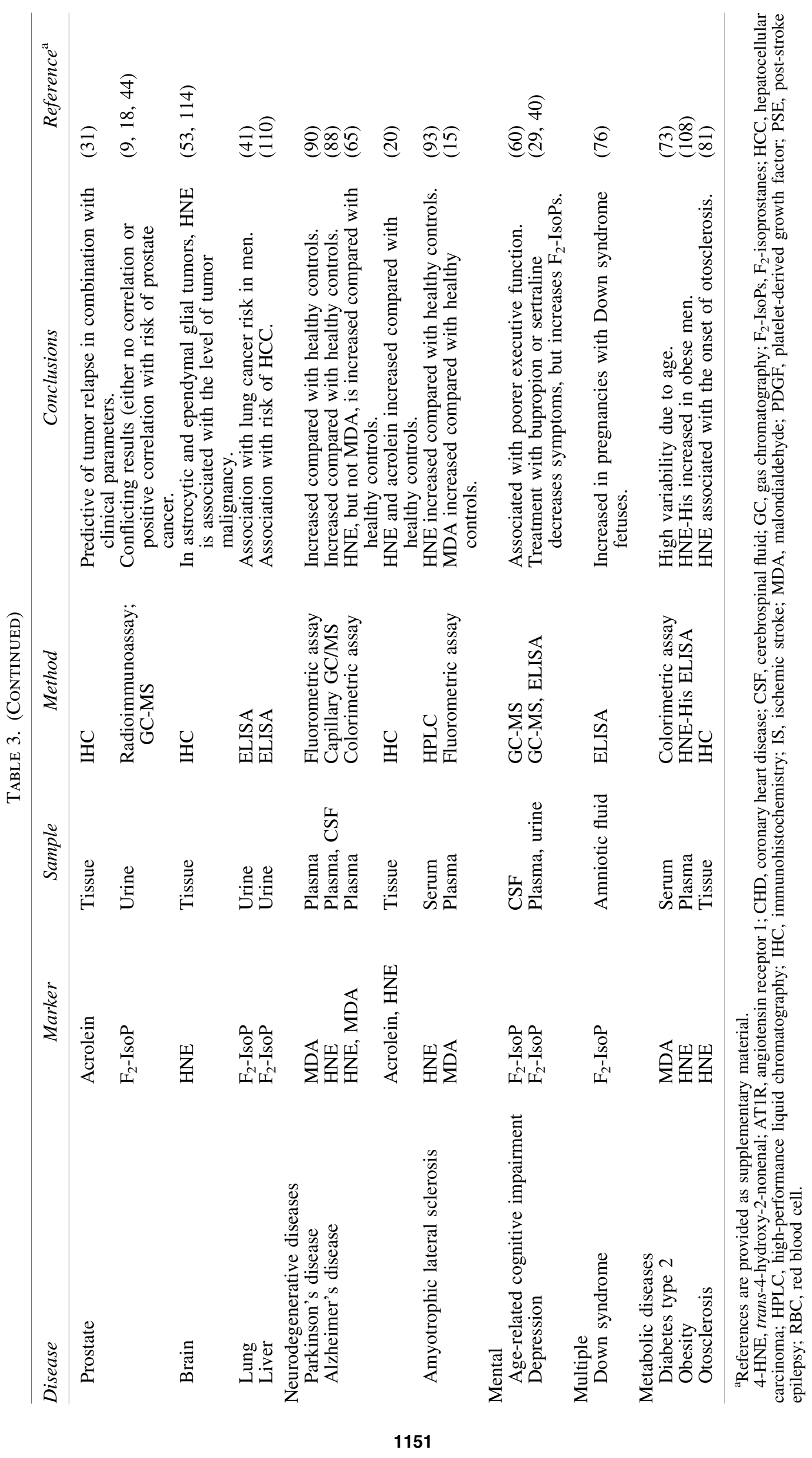


Despite their widespread use, all methods that detect both MDA and 4-HNE have their pitfalls (162). In the thiobarbituric acid reactive substances (TBARS) assay, up to $98 \%$ of the measured MDA can be formed by the hightemperature conditions during the procedure itself (117). When combined with HPLC, MDA-TBA adducts in in vitro oxidized human plasma can be determined reproducibly and reliably, although this method requires individual sample processing and its validity as a marker of in vivo oxidative stress remains uncertain, making it less applicable for routine clinical use (19). The numerous commercial easy-touse kits lack specificity and their significance for clinical research is questionable.

In general, direct MDA and 4-HNE measurement is insensitive as the vast majority of these reactive products are bound to proteins and other biomolecules and remain undetected unless released before the assay (49). To measure the presence of 4-HNE in biological samples, including proteinbound aldehydes, protein immunodetection is preferred, either applied as immunohistochemistry or as HNE-His ELISA (187). The specificity of the monoclonal antibodies against HNE-His adducts allows their use in human and animal tissues, tissue homogenates, and in plasma and serum samples $(63,126,162)$.

\section{$F_{2}$-isoprostanes}

Several thorough reviews of the biochemistry and utility of $\mathrm{F}_{2}$-isoprostanes $\left(\mathrm{F}_{2}\right.$-IsoPs) as biomarkers have been recently published $(39,113,114)$, so only the most seminal points will be summarized here. Oxidation of AA forms a family of 64 bicyclic endoperoxide regio- and stereoisomers collectively termed $\mathrm{H}_{2}$-isoprostanes (140). Nonenzymatic rearrangement of these $\mathrm{H}_{2}$-isoprostanes forms both stable $\mathrm{F}_{2}$-IsoPs and highly reactive $\gamma$-ketoaldehydes termed isolevuglandins (IsoLGs, also known as isoketals) (115). Because of their chemical stability and sensitivity to changes in oxidative stress, $\mathrm{F}_{2}$-IsoPs are often considered the most reliable markers for monitoring oxidative stress in vivo (89). Elevated concentrations of $\mathrm{F}_{2}$-IsoPs are found in CVD, correlate with extent of disease, and predict the outcome (39). Elevated $F_{2}$-IsoPs are also found in a wide range of human clinical conditions (113).

Despite strong evidence for their utility as biomarkers (Table 3 ), one challenge to widespread adaptation of $\mathrm{F}_{2}$-IsoPs in clinical trials is that the most reliable methods for their quantitation, gas chromatography-mass spectrometry (GCMS) and LC-MS/MS, are labor-intensive and require specialized and expensive instrumentation $(7,114)$. While commercial immunoassays have been developed as a cheaper and easier alternative to mass spectrometry (MS), the results obtained with these immunoassays often do not correlate well with those obtained with GC-MS $(78,136)$. Thus, the results from immunoassays, particularly for individual patients, must be used with extreme caution, only with appropriate sample cleanup, and validated by MS whenever possible.

\section{Isolevuglandins}

Similar to F2-IsoPs, IsoLGs are products derived from the oxidation of AA and are sensitive to changes in oxidative stress. While $\mathrm{F}_{2}$-IsoPs are stable products of lipid oxidation,
IsoLGs (Fig. 4) react rapidly and irreversibly with primary amines (e.g., protein lysyl residues and phosphatidylethanolamine) in the cell to form pyrrole (lactam) and oxidized pyrrole (hydroxylactam) adducts $(18,115,146)$. Thus, only IsoLG adducts, and not unreacted IsoLGs, are detected in cells and tissues.

IsoLG adducts may eventually prove to have greater utility as disease biomarkers than more generalized measures of oxidative stress status because they appear to directly participate in pathological processes. The biological effects of exogenous IsoLGs on cultured cells include induction of inflammatory pathways, immune responses, and cell death, as well as inhibiting ion channel function $(17,36,56,65,95)$. These results, along with the therapeutic effects of administering small-molecule IsoLG scavengers in animal models, suggest that IsoLGs could contribute to disease processes, including inflammation, hypertension, arrhythmia, atherosclerosis, and neurodegeneration $(38,41,95,146)$.

Quantitative immunoassays using polyclonal antibodies against IsoLG-protein adducts detected increased IsoLGprotein adduct formation in plasma from patients with atherosclerosis, in plasma from patients with end-stage renal disease, and in the glaucomatous trabecular meshwork (146). Immunohistochemical staining with the single-chain antibody $\mathrm{D} 11 \mathrm{ScF}$ that selectively recognized IsoLG-protein adducts showed increased adducts in the epicardial border zone of myocardial infarcts (56), in the hippocampus of Alzheimer's disease patients (38), and in heart, aorta, and dendritic cells during hypertension (64).

Mass spectrometric methods have demonstrated increased IsoLG-protein adducts compared with controls in the epicardial border zone of myocardial infarcts (56), in the hippocampus of Alzheimer's patients (38), and dendritic cells during hypertension (64). Using MS, IsoLG-phosphatidylethanolamine adducts have been found to be increased in plasma from patients with macular degeneration (102).

Currently, there are no published studies demonstrating that increased levels of IsoLG adducts predict onset or severity of subsequent disease. Therefore, the utility of measuring IsoLG adducts in urine or plasma as clinical biomarkers remains to be established. Nevertheless, current findings provide strong rationale for further investigation of the potential use of IsoLG adducts as clinical biomarkers, both to identify persons at risk and to determine the efficacy of treatments targeting IsoLGs such as dicarbonyl scavengers.

\section{3-Nitrotyrosine}

Nitrotyrosine $\left(\mathrm{Tyr}-\mathrm{NO}_{2}\right)$ is often described as a stable marker of oxidative/nitrative stress in inflammatory diseases (71). Tyrosine nitration involves the replacement of $\mathrm{C}_{3}$ hydrogen atom of the tyrosine aromatic ring with a nitro group $\left(\mathrm{R}-\mathrm{NO}_{2}\right)(11)$ (Fig. 5). This modification can occur within a polypeptide sequence (protein-associated Tyr- $\mathrm{NO}_{2}$ ) or to free tyrosine amino acids (free Tyr- $\mathrm{NO}_{2}$ ). Nitration can occur by several pathways in vivo, but always involves RNS and is usually a two-step process (161), in which (i) tyrosine is oxidized resulting in a tyrosine radical and (ii) a radical-radical reaction occurs between the tyrosine radical and nitrogen dioxide $\left({ }^{\bullet} \mathrm{NO}_{2}\right)$. It is possible for the tyrosine radical to react with nitric oxide ( $\left.{ }^{\circ} \mathrm{NO}\right)$, followed by further oxidation to yield Tyr- $\mathrm{NO}_{2}$, but this pathway has not been well studied (11). 


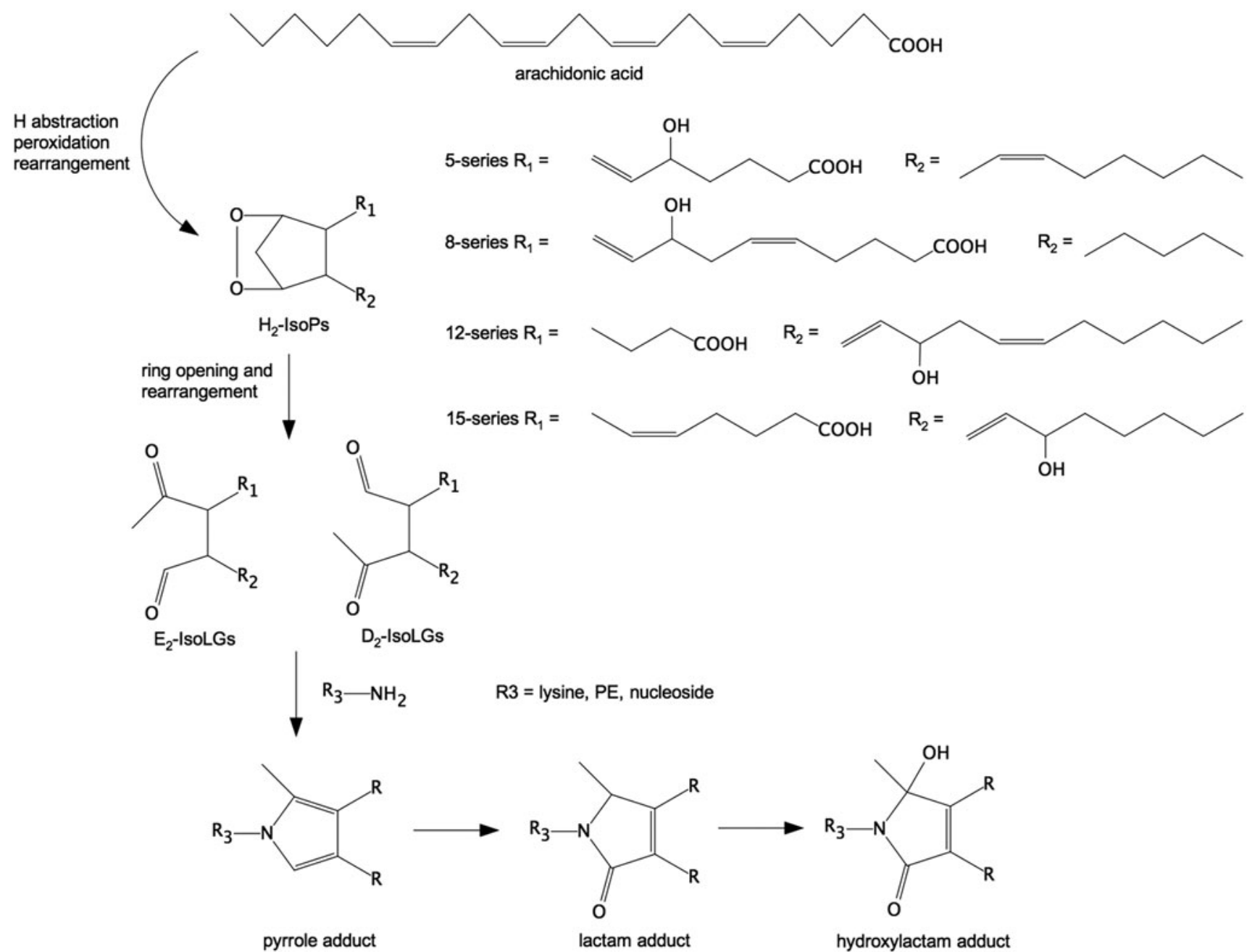

FIG. 4. Regioisomers of isolevuglandins. Specific IsoLG regioisomers differ by the relative orientation of their keto- and aldehyde moieties $\left(\mathrm{D}_{2}\right.$-IsoLG vs. $\mathrm{E}_{2}$-IsoLG) and the position of the double bonds and hydroxyl group on the side chains (5-, $8-, 12-$, or 15-IsoLG) $(37,141,147,148)$. Theoretical considerations from peroxidation chemistry suggest that the 5- and 15-IsoLG series should predominate over the 8- and 12-IsoLG series (198). It is important to recognize that one of the eight stereoisomers of both $15-\mathrm{D}_{2}$-IsoLG and $15-\mathrm{E}_{2}$-IsoLG is chemically identical to levuglandin $\mathrm{D}_{2}$ and $\mathrm{E}_{2}$, respectively, which are generated nonenzymatically from prostaglandin $\mathrm{H}_{2}(149,150)$. IsoLG, isolevuglandins.

One widely studied pathway for nitration is the production of the RNS peroxynitrite $\left(\mathrm{ONOO}^{-}\right)$(Fig. 6, pathway 1) (132). Initially, Tyr- $\mathrm{NO}_{2}$ was believed to be a specific marker of peroxynitrite-mediated damage, but this has since been disproved, with the most-cited alternate pathway involving myeloperoxidase (MPO), as proposed in 1997 (183) (Fig. 6, pathway 2). When solely measuring $\mathrm{Tyr}-\mathrm{NO}_{2}$ in complex biological samples, it is not possible to tell which of the mechanisms is responsible for any nitration detected in vivo. The effect of nitration on protein activity varies with the protein being studied and can be a gain of function (180) or loss of function (195).

The issue of which method to employ for the determination of Tyr- $\mathrm{NO}_{2}$ in the high-throughput analysis of clinical samples needs be addressed as MS, while considered the gold standard (176), is not yet feasible for high-throughput analysis and other methods suffer from methodological flaws or cannot be properly assessed due to a lack of detailed methodological information $(45,197)$. In addition, some authors fail to clearly state whether free Tyr- $\mathrm{NO}_{2}$, protein-associated Tyr- $\mathrm{NO}_{2}$, or total Tyr- $\mathrm{NO}_{2}$ is measured, the concentrations of which may be different. While evidence does suggest that nitration of certain proteins enhances proteolytic degradation (160), a fall in protein-associated Tyr- $\mathrm{NO}_{2}$ concentration will only be measurable if the nitrated protein is degraded in parallel with a decrease in disease activity.

There is still much work to do in assessing the utility of Tyr$\mathrm{NO}_{2}$ as a clinical biomarker, but findings so far are encouraging, with some studies showing that plasma Tyr- $\mathrm{NO}_{2}$ levels correlate with disease activity and decrease following successful therapeutic interventions. Yet, it is still unclear whether Tyr- $\mathrm{NO}_{2}$ is any more informative, in clinical terms, than other already available markers, for example, C-reactive protein (CRP). CRP is an acute phase protein synthesized by the liver in response to signaling by upregulated inflammatory cytokines (e.g., IL-6). Serum CRP is widely used clinically as a marker of acute inflammation, but of course an increase in serum CRP concentration is delayed until some hours after the 


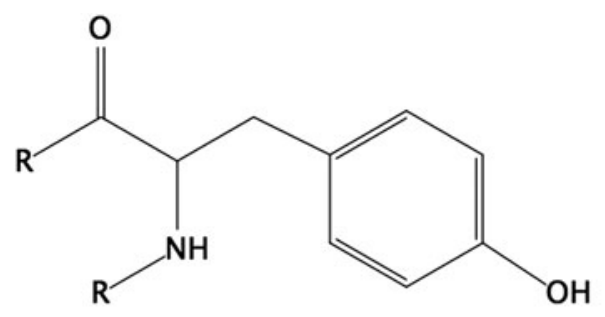

tyrosine

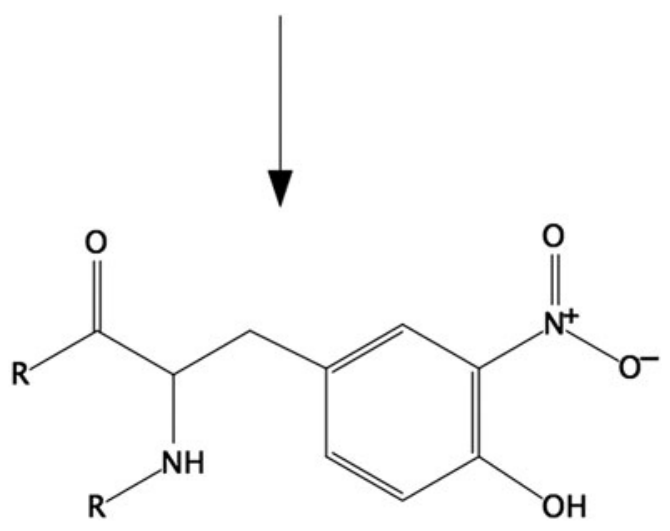

nitrotyrosine

FIG. 5. Structure of 3-nitrotyrosine. Tyrosine nitration involves the replacement of the $\mathrm{C}_{3}$ hydrogen atom of the tyrosine aromatic ring with a nitro group $\left(\mathrm{R}-\mathrm{NO}_{2}\right)$. The 3nitrotyrosine is depicted as part of a polypeptide/protein.

initial inflammatory insult because liver synthesis of CRP protein is required. In contrast, chemical modifications to preexisting cellular or extracellular proteins may occur more swiftly within an inflammatory environment. One application where the measurement of Tyr- $\mathrm{NO}_{2}$ might provide a significant enhancement is in the monitoring of clinical responses to therapy in the assessment of the current pipeline of novel drugs targeted at enzymes involved in ROS generation, for example, NADPH oxidase and MPO inhibitors.

Tyr- $\mathrm{NO}_{2}$ can be detected in tissues by various methods. Among the quantitative approaches, both ELISAs and LC/ GC have been described; however, it is important to note that quantification by ELISAs is limited by several factors: (i) antibodies employed in ELISAs will have different affinities for different nitrated proteins (94), although this is addressed by methods that measure a single nitrated protein (188); (ii) some Tyr- $\mathrm{NO}_{2}$ ELISAs may be prone to interference; and (iii) the sensitivity of some Tyr- $\mathrm{NO}_{2}$ ELISAs may be too low to detect Tyr- $\mathrm{NO}_{2}$ in healthy human plasma. LC/GC has been coupled to various detection systems, for example, UV detection, thermal energy analysis, electrochemical detection, and MS. One explanation for the lack of agreement between reported plasma ELISA- and MS-based Tyr- $\mathrm{NO}_{2}$ plasma concentrations is that the reported ELISA results are based on a nitrated bovine serum albumin standard, in which the actual concentration of nitrated tyrosine residues is unknown.

The National Institute of Environmental Health Biomarkers of Oxidative Stress Study concluded that oxidized

\section{Pathway 1}

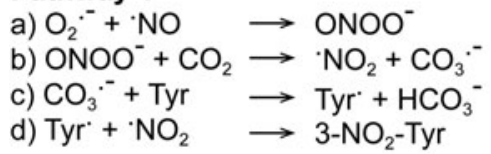

Pathway 2
a) $\mathrm{H}_{2} \mathrm{O}_{2}+$ MPO $\rightarrow$ Compound I $+\mathrm{H}_{2} \mathrm{O}$
b) $\mathrm{NO}_{2}+$ Compound I $\rightarrow$ Compound II $+\cdot \mathrm{NO}_{2}$
c) Compound I + Tyr $\rightarrow$ Compound II + Tyr
d) $\mathrm{Tyr}^{\cdot}+\mathrm{NO}_{2} \quad \longrightarrow$ 3- $\mathrm{NO}_{2}-\mathrm{Tyr}$

FIG. 6. Formation of nitrotyrosine. In pathway 1, peroxynitrite is formed by the reaction of ${ }^{\bullet} \mathrm{NO}$ with the superoxide anion radical $\left(\mathrm{O}_{2}{ }^{\bullet-}\right)$. The enzymatic generation of both these radicals is increased during inflammation. Radical-radical combination of the two species occurs exceedingly fast (rate constant $1 \times 10^{10} \mathrm{M}^{-1} \mathrm{~s}^{-1}$ ), meaning that ${ }^{\circ} \mathrm{NO}$ can outcompete the dismutation of $\mathrm{O}_{2}^{\bullet-}$ by SODs (138). Under physiological conditions in which $\mathrm{CO}_{2}$ is present, nitration via peroxynitrite is increased (3) due to the formation of the adduct $\mathrm{ONOOCO}_{2}^{-}$. This adduct undergoes homolysis to the secondary free radicals, nitrogen dioxide $\left({ }^{\bullet} \mathrm{NO}_{2}\right)$ and carbonate anion radical $\left(\mathrm{CO}_{3}{ }^{--}\right)$(132). $\mathrm{CO}_{3}{ }^{--}$is able to perform step 1 of the nitration process by oxidizing tyrosine to tyrosine radical, which then reacts with the ${ }^{\bullet} \mathrm{NO}_{2}$. In pathway 2 , MPO catalyzes, in the presence of $\mathrm{H}_{2} \mathrm{O}_{2}$ and nitrite $\left(\mathrm{NO}_{2}{ }^{-}\right)$, the production of both the tyrosine radical and ${ }^{\bullet} \mathrm{NO}_{2}(11,132)$. $\mathrm{CO}_{2}$, carbon dioxide; $\mathrm{ONOOCO}_{2}$, nitrosoperoxocarbonate; SODs, superoxide dismutases.

proteins (of which Tyr- $\mathrm{NO}_{2}$ was one of the measured biomarkers) are not suitable biomarkers of free radical damage caused by carbon tetrachloride treatment in rats (89). Nevertheless, many studies have investigated Tyr- $\mathrm{NO}_{2}$ under inflammatory conditions as a marker of oxidative stress and have found plasma Tyr- $\mathrm{NO}_{2}$ concentrations to be higher in patients in a variety of diseases (summarized in Table 4). Some of the clinically relevant findings include the association of higher Tyr- $\mathrm{NO}_{2}$ levels with higher mortality in sepsis and a fall in plasma Tyr- $\mathrm{NO}_{2}$ concentration, as well as a correlation with other markers following treatment with various anti-inflammatory drugs. In addition, two studies using different methodologies reported a lowering of plasma protein-associated Tyr- $\mathrm{NO}_{2}$ concentrations upon drug treatment (statins in coronary artery disease and rosuvastatin in hypercholesterolemia). Tyr- $\mathrm{NO}_{2}$ may not only be a potential biomarker of oxidative stress in diabetes patients $(28,29)$ but may also be a biomarker of disease progression/risk for CVD (111a). In asthmatic patients, $\mathrm{Tyr}-\mathrm{NO}_{2}$ staining in bronchial biopsies and measurement of Tyr- $\mathrm{NO}_{2}$ by ELISA in exhaled breath condensates both showed a decrease of Tyr- $\mathrm{NO}_{2}$ upon corticosteroid treatment. Conflicting results were obtained in neurodegenerative disorders; although Tyr- $\mathrm{NO}_{2}$ has been reported at increased levels within brain tissue from Parkinson's (60) and Alzheimer's disease patients (167), free Tyr$\mathrm{NO}_{2}$ is not increased in the cerebrospinal fluid of Alzheimer's disease patients (143). Likewise, protein-bound Tyr- $\mathrm{NO}_{2}$ is not increased in plasma of patients with dementia (44). In contrast, nitrated $\alpha$-synuclein was detected in peripheral blood mononuclear cells from Parkinson's disease patients, the concentrations of which were inversely correlated with the daily dosage of levodopa (Table 4). 


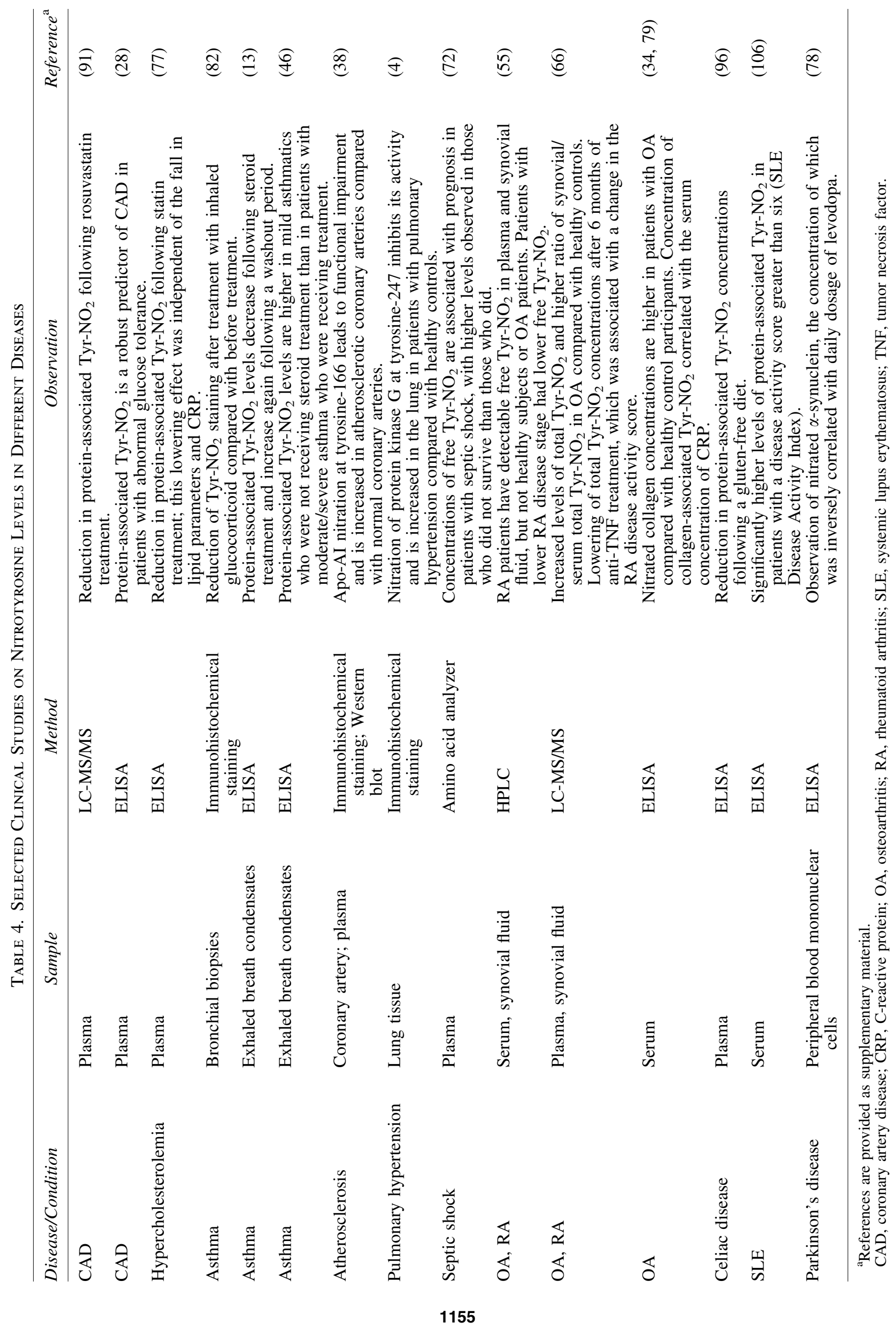


Thiols

The main thiol compound in the body is the amino acid cysteine, which is susceptible to oxidation. Oxidation of a cysteine residue can change a protein's function. Thus, measuring the thiol status may represent a mechanism-based biomarker. Biologically occurring thiols include low-molecularweight thiols (cysteine, GSH) and protein thiols.

The use of thiols as biomarkers is affected by a number of factors. In addition to specific limitations for those thiols that are only present intracellularly, a general problem is that oxidation products of protein cysteine residues are unstable. They can be easily reduced by other thiols and thus require immediate treatment with an alkylating agent to prevent further redox changes. A change in GSH levels might not be due to oxidative stress, but might reflect a nutritional/metabolic imbalance. Plasma GSH levels may also be affected by GSH transporters, while cellular mechanisms, such as nuclear factor (erythroid-derived 2)like 2 (NRF2), counteract oxidative stress by increasing GSH synthesis. Finally, oxidized glutathione (GSSG) concentrations are very low and difficult to measure unless sensitive HPLC methods are used.

\section{Glutathione}

The main nonprotein thiol is the tripeptide GSH. Since intracellular concentrations of GSH are high, in the millimolar range, it is an important component of antioxidant defense systems to scavenge ROS, which leads to GSSG. Oxidation of GSH is reversible as GSSG reductase and NADPH reduce GSSG back to two molecules of GSH.

In general, any condition associated with excessive ROS will decrease GSH levels or decrease the GSH/GSSG ratio. Within cells, GSH is present at millimolar concentrations, resulting in high GSH/GSSG ratios (>30) (76). The GSH/ GSSG ratio in serum is substantially lower $(\sim 3)$. Whether this meaningfully reflects a cellular redox state is questionable (90) and it may not be a good indicator of oxidative stress (86). Thus, most studies measure erythrocyte GSH where GSH concentrations are high, but not necessarily a good indicator of oxidative stress across tissues. Furthermore, lower GSH levels may not necessarily be due to oxidation, but rather due to a consequence of lower cysteine levels (cysteine is the rate-limiting GSH precursor) due to nutritional deficiency. Nevertheless, many studies have measured plasma GSH/GSSG. Three meta-analyses confirmed a decrease in plasma GSH and an increase in plasma GSSG in patients with autism spectrum disorders (54) and lower plasma GSH levels in polycystic ovary syndrome (121), two conditions in which oxidative stress has been implicated $(127,144)$. It should be noted that these meta-analyses are based on studies where GSH/GSSG are measured by a variety of techniques, including enzymatic methods, HPLC with fluorometric, UV, or electrochemical detectors, and LC-MS/MS.

Several pathological conditions are associated with decreased GSH levels (6). In particular, studies on GSH in acquired immunodeficiency syndrome (AIDS) and other conditions have shown very clearly that rather than in plasma, GSH should be measured within cells by fluorescence activated cell sorting (72). GSH measurement is important to identify patients who may benefit from GSH repletion by GSH derivatives or precursors, for example, in clinical trials (6).

\section{Cysteine}

Free cysteine is the main nonprotein thiol in plasma (86, 118). Studies have measured plasma cysteine $(\sim 10 \mu M)$ and its disulfide, cystine $(\sim 40-50 \mu M)$, in CVDs with varying results $(43,112)$. Cysteine is a semiessential amino acid and its requirement may increase following oxidative stress due to the consumption of GSH (6). Historically, one important condition associated with lower plasma cysteine is AIDS, originally reported by the group of Droge (46).

\section{Protein thiols and mixed disulfides}

Protein cysteine residues can exist in many oxidation states (Fig. 7). Protein glutathionylation (mixed disulfides with GSH) received particular attention. Significant amounts of glutathionylated proteins are detected under normal conditions or following exposure to oxidants $(58,156)$. Most of the glutathionylated proteins are intracellular because GSH is predominantly present in the cytoplasm and intracellular proteins have cysteine residues predominantly in the chemically reduced state and thus are available to form mixed disulfides, in contrast to extracellular proteins where most cysteine residues are engaged in disulfide bridges.

The only plasma protein identified as glutathionylated is transthyretin (58). Many studies propose glutathionylated hemoglobin, measured in red blood cells by MS, as a biomarker of oxidative stress in diabetes, hyperlipidemia, hemodialysis, and chronic renal failure $(31,58)$. An increase in plasma cysteinylated albumin, measured by MS, has also been reported in chronic liver and kidney diseases and diabetes (124).

\section{Surface thiols}

The plasma membrane is the interface between the reducing intracellular and the oxidizing extracellular environments. While one might expect the extracellular (exofacial) membrane thiols to be oxidized, they are in fact not, and

\begin{tabular}{|c|l|l|l|}
\hline-2 & $-\mathrm{SH}$ & $\begin{array}{l}\text { Free thiol } \\
\text { (sulfhydryl) }\end{array}$ & \\
\hline-1 & $-\mathrm{SS}-$ & Disulfide & $\begin{array}{l}\text { Protein-Protein (P-SS-P) } \\
\text { Protein-Glutathione (P-SSG) } \\
\text { Protein-Cysteine (P-SSC) } \\
\text { Reversible oxidation }\end{array}$ \\
\hline $\mathbf{0}$ & $\begin{array}{l}-\mathrm{SNO} \\
-\mathrm{SOH}\end{array}$ & $\begin{array}{l}\text { S-nitrosothiol } \\
\text { Sulfenic acid }\end{array}$ & Reversible oxidation \\
\hline $\mathbf{2}$ & $-\mathrm{SO}_{2} \mathrm{H}$ & Sulfinic acid & Reversible oxidation* \\
\hline+4 & $-\mathrm{SO}_{3} \mathrm{H}$ & Sulfonic acid & Irreversible oxidation \\
\hline
\end{tabular}

FIG. 7. Protein cysteine oxidation states. Cysteine residues in proteins can exist in different oxidation states, ranging from reduced free thiols to reversible oxidized forms (disulfides, S-nitrosothiols, sulfenic acids, and sulfinic acids) to irreversible sulfonic acids. *Reversibility of protein cysteine sulfinic acids has so far been demonstrated only for some sulfinylated peroxiredoxins and requires the enzymatic activity of sulfiredoxin. 


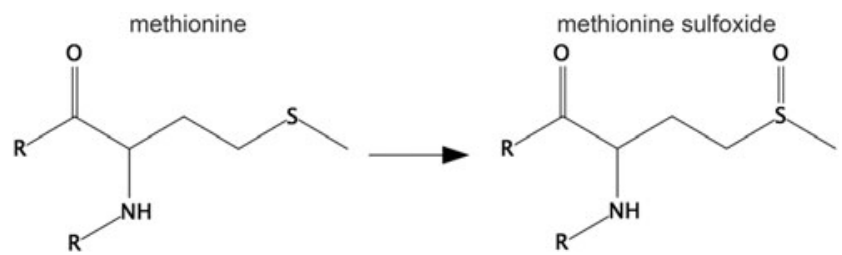

FIG. 8. Structure of methionine sulfoxide. Methionine contains a sulfur atom that is also susceptible to oxidation and can give rise to methionine sulfoxide. The methionine sulfoxide is depicted as part of a polypeptide/protein.

active mechanisms maintain specific surface thiols (98), with surface thiols lower in rheumatoid arthritis (RA) (131). Their measurement may provide additional information on the redox state of a patient (145).

\section{Methionine sulfoxide}

Methionine is the other sulfur-containing amino acid beside cysteine (Fig. 8). Sulfur in methionine can be reversibly oxidized by ROS to a sulfoxide. Oxidation of an essential methionine in the abundant serum protein $\alpha$-1-proteinase inhibitor leads to its inactivation (85). Elevated levels of this sulfoxidized form have been detected in the bronchoalveolar lavage of smokers, contributing to the pathogenesis of emphysema (27). The presence of methionine sulfoxide in plasma proteins and in HDL is increased in sepsis and diabetes $(5,21)$. Although not as widely studied as a form of thiol oxidation, methionine sulfoxide has potential advantages as a biomarker: it is easily measured with a conventional amino acid analyzer and is more stable than thiol oxidation products.

\section{DNA/RNA oxidation}

Oxidative stress induces oxidation of DNA and RNA (Fig. 9), particularly in the guanine moiety. The oxidized nucleosides are excreted into the urine and their measurement can be interpreted as the cumulative total body oxidative stress, that is, number of hits to the nucleic acids in a defined time period, meaning the global rate of DNA and RNA oxidation. Therefore, as urinary biomarkers, they are most relevant to conditions where oxidative stress occurs in all tissues in the body and less to high oxidative stress in minor organs without assumed systemic oxidative stress. Several commercial assays are available to measure 7,8-dihydro-8-oxo-2'-
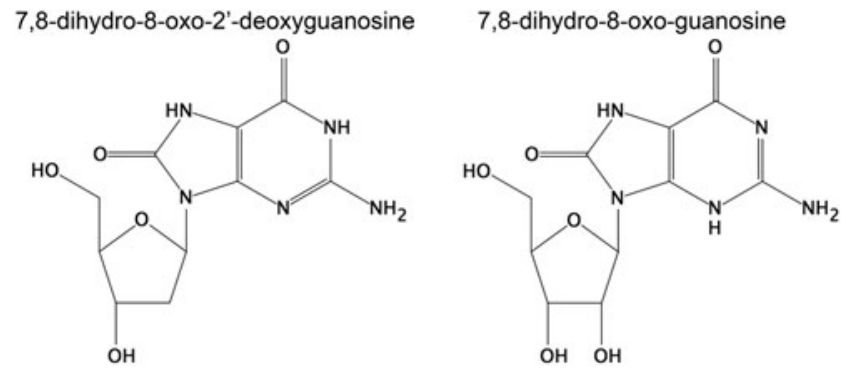

FIG. 9. Structure of 8-oxo-2'-deoxyguanosine and 8oxo-guanosine. Oxidation of DNA and RNA commonly occurs in the guanosine moiety, leading to 8-oxo- $2^{\prime}$ deoxyguanosine and 8-oxo-guanosine, respectively. deoxyguanosine (8oxodG) with ELISA. However, the clinical significance of these methods has been questioned (10). While chromatography coupled to MS may not be readily available clinically, biomarkers for oxidative stress measured by oxidation of nucleic acids are among-if not the bestbiomarkers that have been examined. Nucleic acid oxidation products have also been demonstrated to be predictive of the development of disease $(22,23)$.

The oxidative modification in DNA can cause mispair and thereby lead to mutations, particularly GC-TA transversion mutations, and therefore relates to cancer $(104,134)$. Oxidative lesions in DNA are recognized by repair enzymes; the nucleotide pool can be oxidized, but is sanitized by other enzyme systems (133). There is some debate as to whether the lesions in DNA relate to incorporation from the nucleotide pool or direct oxidation in DNA (70). Chronically high oxidation of DNA, measured as urinary excretion of the nucleoside 8oxodG, is associated with risk of lung and breast cancer $(103,105)$.

Recently, RNA oxidation, measured as 7,8-dihydro-8-oxoguanosine (8oxoGuo), has been introduced as a marker in relation to diseases, particularly neurodegenerative diseases and diabetes $(22,23,88)$. Because of the single strand nature of RNA, repair is not possible. Remarkably, relatively little is known about how RNA integrity is maintained, but it is assumed to rely on quality control and degradation (133). The cellular effects of RNA oxidation also remain largely obscure, although formation of truncated or mutated proteins has been suggested $(133,135)$. There are indications of formation of mutated proteins (170) and of microsomal stalling induced by oxidized RNAs (159). Very recently, advanced methodology has demonstrated that the effects of RNA lesions fall into two categories, one that includes ribosomal stalling and one that leads to a mixture of full length and truncated translational products (26). It thus appears that nucleic acid oxidation/modification has much more diverse and multifaceted biological effects, exemplified both with different effects on translation stalling and also in the target molecule, for example, in diabetes where RNA oxidation is not only more pronounced than DNA oxidation but also has a very different prognostic value.

Extensive DNA oxidation is predictive for the risk of breast and lung cancer $(103,105)$. Elevated RNA oxidation is predictive for development of complications and death in type 2 diabetes, and there are indications that high RNA oxidation is associated with breast cancer development in type 2 diabetic females (22). Thus, screening for urinary DNA/RNA oxidation could help to identify such people and patients at risk and help to implement a treatment plan to minimize it.

For measurement of 8oxodG and 8oxoGuo in urine, the most reliable methodology is chromatography coupled with MS (189-191). 8oxodG can also be measured by HPLCelectrochemical detection, which is rarely used presently.

\section{Markers of ROS Generation}

Some ROS-forming enzymes that are normally present intracellularly can also be found in the circulation, independently of the mechanism responsible for their release. For this reason, we will only describe xanthine oxidase (XO) and MPO. Higher circulating levels of XO and MPO 
could potentially result in increased ROS production, although this depends on other factors such as availability of the substrate (xanthine for $\mathrm{XO}$ and $\mathrm{H}_{2} \mathrm{O}_{2}$ for MPO) and whether ROS produced by these enzymes overcome the antioxidant defense. In some cases, a better indicator of the enzyme activity in vivo is the formation of the metabolite or reaction product.

\section{Xanthine oxidase}

XO catalyzes the oxidation of xanthine to uric acid. While the product is a known antioxidant (4), the enzyme is also a well-known source of $\mathrm{O}_{2}{ }^{--}$(109). Inflammatory agents and interferon increase XO activity and its plasma levels (59). However, the most important translational breakthrough was the hypothesis of the role of XO in ischemia-reperfusion injury (108). This led to several, ongoing clinical trials with XO inhibitors in CVD and prompted many studies to measure circulating XO (12). It should be mentioned that XO inhibition has other effects than inhibiting ROS production. In particular, by decreasing uric acid, it may improve CVD by lowering hyperuricemia (14), and uric acid is not only an antioxidant (4) but also proinflammatory through activation of the NALP3 inflammasome (107).

While we list XO among the ROS-generating enzymes, it could also be an indicator of oxidative stress. In fact, the protein exists in two forms, an oxidase (that oxidizes xanthine to uric acid using oxygen as the electron acceptor and produces $\mathrm{H}_{2} \mathrm{O}_{2}$ ) and a dehydrogenase (that carries out the same reaction, but uses $\mathrm{NAD}^{+}$and generates $\left.\mathrm{NADH}\right)$. The dehydrogenase form can be converted into XO by, among other things, thiol oxidation (48). Thus, oxidative stress will increase XO activity by increasing dehydrogenase-to-oxidase conversion.

\section{Myeloperoxidase}

MPO is a heme peroxidase that catalyzes the reaction between $\mathrm{H}_{2} \mathrm{O}_{2}$ and chloride ions to produce $\mathrm{HOCl}$ as the primary oxidant. These are not only important in the innate immune system's antimicrobial activities but also contribute to inflammatory diseases, such as atherosclerosis and related vascular diseases (35) and Parkinson's and Alzheimer's disease $(32,123,139)$, via multiple mechanisms (166).

The suitability of MPO as a potential independent prognostic biomarker of inflammation is summarized in Table 5. A limitation of MPO as a biomarker is that current methods are not standardized between laboratories and do not provide direct information on MPO activity. The methods used to directly measure MPO activity as well as biomarkers specific for MPO have been reviewed recently (92). MPO-derived oxidants generate a footprint of specific and nonspecific oxidation products. 3-Chlorotyrosine (3-Cl-Tyr) and chlorinated lipids, as well as glutathione sulfonamide, are specific products for $\mathrm{MPO} / \mathrm{HOCl}$ (92). Nonspecific oxidation products include protein carbonyls and 3-nitrotyrosine modifications. Of the specific biomarkers, 3-Cl-Tyr has received the most attention and has been detected in a wide variety of diseases (Table 6).

Chlorinated lipids have been detected in human atherosclerotic plaque (173). 2-Chloradipic acid (185) is excreted in urine and hence offers the potential as a biomarker. Glutathione sulfonamide is present in the airways of preterm infants with respiratory disease as well as in children suffering from cystic fibrosis (93).

A general limitation of the specific biomarkers of MPO activity is the requirement for expensive equipment and timeconsuming sample workup and analysis. Often, concentration of these biomarkers in biological samples is low, which complicates accurate measurement. As a result, investigators have fractionated plasma and observed that HDL can be the major carrier of 3-Cl-Tyr in CVD (15). However, the extensive preparation procedures for HDL analysis limit its clinical use. Glutathione sulfonamide is a relatively minor oxidation product derived from the reaction of reduced glutathione (GSH) with $\mathrm{HOCl}$. This limits its application to biological samples that contain significant amounts of GSH. Plasma, which has very little GSH, is therefore not a suitable source to analyze glutathione sulfonamide.

Within these limitations, the determination of MPO protein is a reasonable approach to at least initially assess a potential contribution of MPO-mediated oxidative damage to a disease, and in most studies, MPO and specific MPO activity biomarkers with different specificities provide similar results (Tables 5 and 6).

\section{Markers of Antioxidant Defense}

In principle, oxidative stress can also derive from an impaired antioxidant defense. We focus here not only on protein thiol-disulfide oxidoreductases that can be measured in serum or plasma but also the transcription factor NRF2 that drives the transcription of several antioxidant genes. NRF2 is activated in response to oxidative stress and its activation could therefore be used as an indicator of ROS generation that exceeded the existing antioxidant defense systems.

\section{Protein thiol-disulfide oxidoreductases}

These enzymes include, among others, thioredoxin (Trx) and peroxiredoxins (Prxs; Fig. 10). Trx main function is to keep protein thiols in the reduced state. For this reason, Trx is often regarded as an antioxidant enzyme. Secretion of Trx was originally discovered in leukemia cells by virologist Junji Yodoi, who initially thought he had identified interleukin- $1-\gamma$ (199). While it cannot be excluded that Trx secretion may be induced by other factors, it is thought that its secretion is induced by oxidative stress. Its secretion is inhibited by antioxidants in vitro (96) and its plasma levels are elevated in cancer patients (8) and AIDS patients, where it negatively correlates with survival (125). Various reports have suggested that plasma/serum Trx concentrations are diagnostically relevant in a range of diseases. For instance, Qi et al. found that serum Trx concentrations reflected disease severity in acute ischemic stroke (137), and the addition of Trx to an established disease severity score provided a significant improvement in diagnostic capacity.

The Prx family has a key role in the elimination of $\mathrm{H}_{2} \mathrm{O}_{2}$ because it is highly abundant and reacts with $\mathrm{H}_{2} \mathrm{O}_{2}$ at high rates. Prxs are often identified in proteomics studies and several studies identified Prxs in the secretome under various disease conditions (80). In particular, oxidized Prx6 in the cerebrospinal fluid has been proposed as a biomarker of oxidative stress in brain injury, where it is a good predictor of the outcome (106). The importance of the redox state of Prxs as biomarkers is also demonstrated by studies showing that 
Table 5. Selected Clinical Studies on MPO Levels in Different Diseases

\begin{tabular}{|c|c|c|c|c|}
\hline Disease/Condition & Sample & Method & Observation & Reference $^{\mathrm{a}}$ \\
\hline Cardiovascular disease & Serum & $\begin{array}{l}\text { High-sensitivity } \\
\text { sandwich ELISA }\end{array}$ & $\begin{array}{l}\text { MPO independently predicted endothelial } \\
\text { dysfunction better than CRP. }\end{array}$ & (103) \\
\hline $\begin{array}{l}\text { Acute coronary } \\
\text { syndrome }\end{array}$ & Serum & ELISA & $\begin{array}{l}\text { Increased risk for future cardiac events in } \\
\text { patients with elevated serum MPO.MPO, } \\
\text { soluble CD40 ligand, and TnT are } \\
\text { independent predictors of adverse } \\
\text { outcome. }\end{array}$ & (7) \\
\hline $\begin{array}{l}\text { Acute chest pain, } \\
\text { incident MACE }\end{array}$ & Plasma & $\begin{array}{l}\text { Commercial } \\
\text { immuno-based } \\
\text { assay }\end{array}$ & $\begin{array}{l}\text { MPO higher in MACE patients at } \\
\text { hospitalization. MPO predictive for } \\
\text { MACE in patients with normal cardiac } \\
\text { TnT. }\end{array}$ & (71) \\
\hline $\begin{array}{l}\text { Cardiovascular disease } \\
\text { (LURIC study) }\end{array}$ & Plasma & $\begin{array}{l}\text { ELISA (MPO) and } \\
\text { PCR (MPO } \\
\text { polymorphisms) }\end{array}$ & $\begin{array}{l}\text { High MPO predicted mortality independent } \\
\text { of established cardiovascular risk } \\
\text { factors.Five of eight MPO } \\
\text { polymorphisms associated with } \\
\text { increased MPO. No association of MPO } \\
\text { genotype with mortality. }\end{array}$ & (84) \\
\hline $\begin{array}{l}\text { Major adverse cardiac } \\
\text { events }\end{array}$ & Plasma & $\begin{array}{l}\text { Commercial } \\
\text { immuno-based } \\
\text { assay }\end{array}$ & $\begin{array}{l}\text { MPO included in CBS used to predict } \\
\text { future MACEs. High CBS predicted } \\
\text { increased risk of MACEs at } 3 \text { years. }\end{array}$ & (98) \\
\hline $\begin{array}{l}\text { Major adverse cardiac } \\
\text { events }\end{array}$ & Plasma & $\begin{array}{l}\text { Commercial } \\
\text { immuno-based } \\
\text { assay }\end{array}$ & $\begin{array}{l}\text { Patient with MPO }>322 \mathrm{pmol} / \mathrm{L} \text { had } \\
\text { increased risk of developing future } \\
\text { MACE. }\end{array}$ & $(100)$ \\
\hline Chest pain & Plasma & ELISA & $\begin{array}{l}\text { MPO elevated at baseline and } 2 \mathrm{~h} \text { after } \\
\text { onset of symptoms, correlated with TnT } \\
\text { concentration, and is an independent } \\
\text { predictor of MI and CVD risk. }\end{array}$ & (16) \\
\hline Myocardial infarction & Plasma & ELISA & $\begin{array}{l}\text { MPO increased and independently } \\
\text { predicted development of myocardial } \\
\text { infarction in the ensuing } 24 \text { months. }\end{array}$ & $(21)$ \\
\hline Myocardial infarction & Plasma & ELISA & $\begin{array}{l}\text { MPO higher in patients than controls and a } \\
\text { predictor of death or nonfatal MI. }\end{array}$ & (56) \\
\hline Heart failure & Plasma & Cardio MPO test & $\begin{array}{l}\text { High plasma MPO independently predicted } \\
\text { the development of heart failure in } \\
\text { apparently healthy elderly subjects. }\end{array}$ & (99) \\
\hline $\begin{array}{l}\text { Peripheral artery } \\
\text { disease }\end{array}$ & Serum & $\begin{array}{l}\text { Solid-phase } \\
\text { sandwich ELISA }\end{array}$ & $\begin{array}{l}\text { High MPO associated with low ankle- } \\
\text { brachial index and PAD independent of } \\
\text { CRP. }\end{array}$ & (6) \\
\hline $\begin{array}{l}\text { Obesity, cardiovascular } \\
\text { disease }\end{array}$ & Plasma & $\begin{array}{l}\text { Particle-enhanced } \\
\text { turbidimetric } \\
\text { immunoassay }\end{array}$ & $\begin{array}{l}\text { MPO, IL- } 6 \text {, and TNF- } \alpha \text { were higher in } \\
\text { obese than control children and } \\
\text { associated with higher cardiovascular } \\
\text { risk compared with control. }\end{array}$ & (74) \\
\hline $\begin{array}{l}\text { Chronic obstructive } \\
\text { pulmonary disease }\end{array}$ & Serum & ELISA & $\begin{array}{l}\text { MPO increased in patients during acute } \\
\text { exacerbations and persisted for months } \\
\text { following acute illness. }\end{array}$ & (67) \\
\hline Alzheimer's disease & Plasma & Sandwich ELISA & $\begin{array}{l}\text { MPO positively associated with the } \\
\text { presence of Alzheimer's disease, } \\
\text { correlated with A } \beta_{1-42 / 1-40} \text { ratio, and may } \\
\text { potentially be an ideal biomarker for } \\
\text { Alzheimer's disease. }\end{array}$ & $(101)$ \\
\hline Cognitive decline & Plasma & Sandwich ELISA & $\begin{array}{l}\text { Biomarkers of low-grade inflammation, } \\
\text { including MPO, and endothelial } \\
\text { dysfunction correlated with increased } \\
\text { vascular risk and reduced cognitive } \\
\text { ability in an older population. }\end{array}$ & (48) \\
\hline
\end{tabular}

${ }^{\mathrm{a}}$ References are provided as supplementary information.

CBS, cardiac biomarker score; CVD, cardiovascular disease; IL-6, interleukin-6; MACE, major adverse cardiac event; MI, myocardial infarct; MPO, myeloperoxidase; PAD, peripheral artery disease; PCR, polymerase chain reaction; TnT, troponin T. 
Table 6. Selected Clinical Studies on Specific Markers of MPO Activity in Different Diseases

\begin{tabular}{|c|c|c|c|c|}
\hline $\begin{array}{l}\text { Diseasel } \\
\text { Condition }\end{array}$ & Sample & Method & Observation & Reference $^{\mathrm{a}}$ \\
\hline $\begin{array}{l}\text { Acute myocardial } \\
\text { infarction }\end{array}$ & Plasma & $\begin{array}{l}\text { ELISA (MPO), HPLC } \\
\quad(3-C l-T y r)\end{array}$ & $\begin{array}{l}\text { Plasma MPO and } 3 \text { Cl-Tyr increased in } \\
\text { AMI, and AMI incidence increased } \\
\text { with higher MPO and 3-Cl-Tyr. }\end{array}$ & (26) \\
\hline $\begin{array}{l}\text { Coronary artery } \\
\text { disease, Acute } \\
\text { coronary } \\
\text { syndrome }\end{array}$ & Plasma, HDL & $\begin{array}{l}\text { Turbidimetric } \\
\text { immunoassay (MPO) } \\
\text { LC-MS/MS } \\
\text { (3 Cl-Tyr) }\end{array}$ & $\begin{array}{l}\text { No difference in plasma MPO, but } \\
\text { increased 3-Cl-Tyr in HDL of subjects } \\
\text { with CAD/ACS. HDL-associated } \\
\text { 3-Cl-Tyr may be a better biomarker of } \\
\text { CAD/ACS than plasma MPO. }\end{array}$ & (89) \\
\hline CVD & apoB-100 & LC-MS/MS & $\begin{array}{l}\text { Different apoB-100-derived peptides with } \\
\text { modifications characteristic of active } \\
\text { MPO are present in humans with } \\
\text { increased risk for CVD. }\end{array}$ & (35) \\
\hline $\begin{array}{l}\text { Rheumatoid } \\
\text { arthritis }\end{array}$ & Synovial fluid & $\begin{array}{l}\text { ELISA (MPO), } \\
\text { LC-MS/MS } \\
\text { (3 Cl-Tyr) }\end{array}$ & $\begin{array}{l}\text { MPO higher in patients than controls. } \\
\text { MPO protein } 20 \text {-fold higher in synovial } \\
\text { fluid compared with plasma in RA. } \\
\text { 3-Cl-Tyr detected in synovial fluid of } \\
\text { patients with rheumatoid arthritis. }\end{array}$ & (95) \\
\hline $\begin{array}{l}\text { Rheumatoid } \\
\text { arthritis }\end{array}$ & HDL & MS/MS & $\begin{array}{l}\text { Subjects with RA have increased 3-Cl-Tyr } \\
\text { and Tyr-NO } \mathrm{N}_{2} \text { in HDL. MPO-mediated } \\
\text { HDL oxidation is regiospecific in RA } \\
\text { and further exacerbated with } \\
\text { cardiovascular disease. }\end{array}$ & (104) \\
\hline $\begin{array}{l}\text { Rheumatoid } \\
\text { arthritis, } \\
\text { Osteoarthritis }\end{array}$ & Synovial fluid & $\begin{array}{l}\text { Spectrophotometer } \\
\left(\alpha_{2} \mathrm{M}\right) \text { and GC-MS } \\
(3 \mathrm{Cl}-\mathrm{Tyr})\end{array}$ & $\begin{array}{l}\alpha_{2} \mathrm{M} \text { more oxidized and inactivated in RA, } \\
\text { and } 3-\mathrm{Cl} \text {-Tyr elevated in RA compared } \\
\text { with OA. }\end{array}$ & (111) \\
\hline Preterm infants & Tracheal aspirate & LC-MS/MS & $\begin{array}{l}\text { 3-Cl-Tyr concentration was elevated in } \\
\text { infants who developed chronic lung } \\
\text { disease or had lung infection. }\end{array}$ & (19) \\
\hline
\end{tabular}

${ }^{\mathrm{a}}$ References are provided as supplementary material.

AMI, acute myocardial infarction; ACS, acute coronary syndrome; HDL, high-density lipoprotein.

Prx2 is secreted via a nonclassical pathway by inflammatory cells (151) independently of cell death (30) and is present in the serum and synovial fluid of RA patients (168). Bayer et al. (13) have shown in vivo that erythrocyte Prx2 undergoes a transient overoxidation following lipopolysaccharide exposure, and released Prx $1 / 2$ is present in the oxidized form ( 30 , 151), suggesting that its redox state, not just its levels, can be an early marker of oxidative stress.

Human serum Prx4 has also been proposed as a diagnostic marker of oxidative stress in diabetes (1).

\section{Nuclear factor (erythroid-derived 2)-like 2}

The transcription factor NRF2 is considered a prognostic biomarker in cancer. It is found constitutively and at very high levels in biopsies of malignant tumors with high proliferation rates and poor response to anticancer drugs. NRF2 is a master regulator of the antioxidant response that controls the expression of about 250 genes. Some of these genes encode antioxidant enzymes, including those involved in synthesis and use of GSH and Trx, or participate in metabolic reactions that generate reductive power in the form of NADPH. Others participate in phase II biotransformation reactions and phase III external transport of toxins. Thus, high and constitutive activity of NRF2 provides transformed cells with a defense against the ROS that are generated during active proliferation, while at the same time reducing the effective dose of certain anticancer drugs. To date, a prognostic

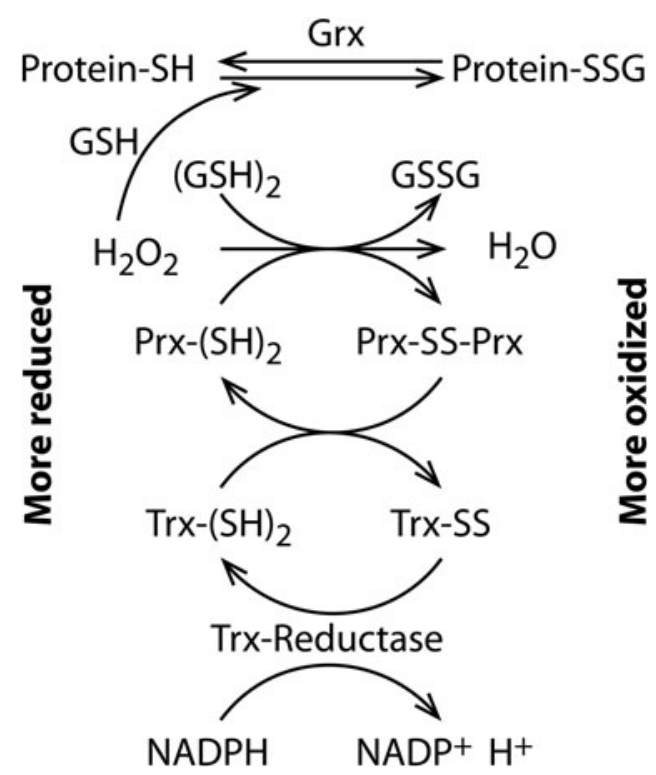

FIG. 10. Protein thiol-disulfide oxidoreductases regulate the redox state of protein thiols. Different thiol compounds can be present under different redox states, depending on the overall redox state of the cell, from the more reduced (left) to more oxidized (right), and the significance of a specific biomarker will depend on its intracellular localization, tissue expression, and redox potential. 


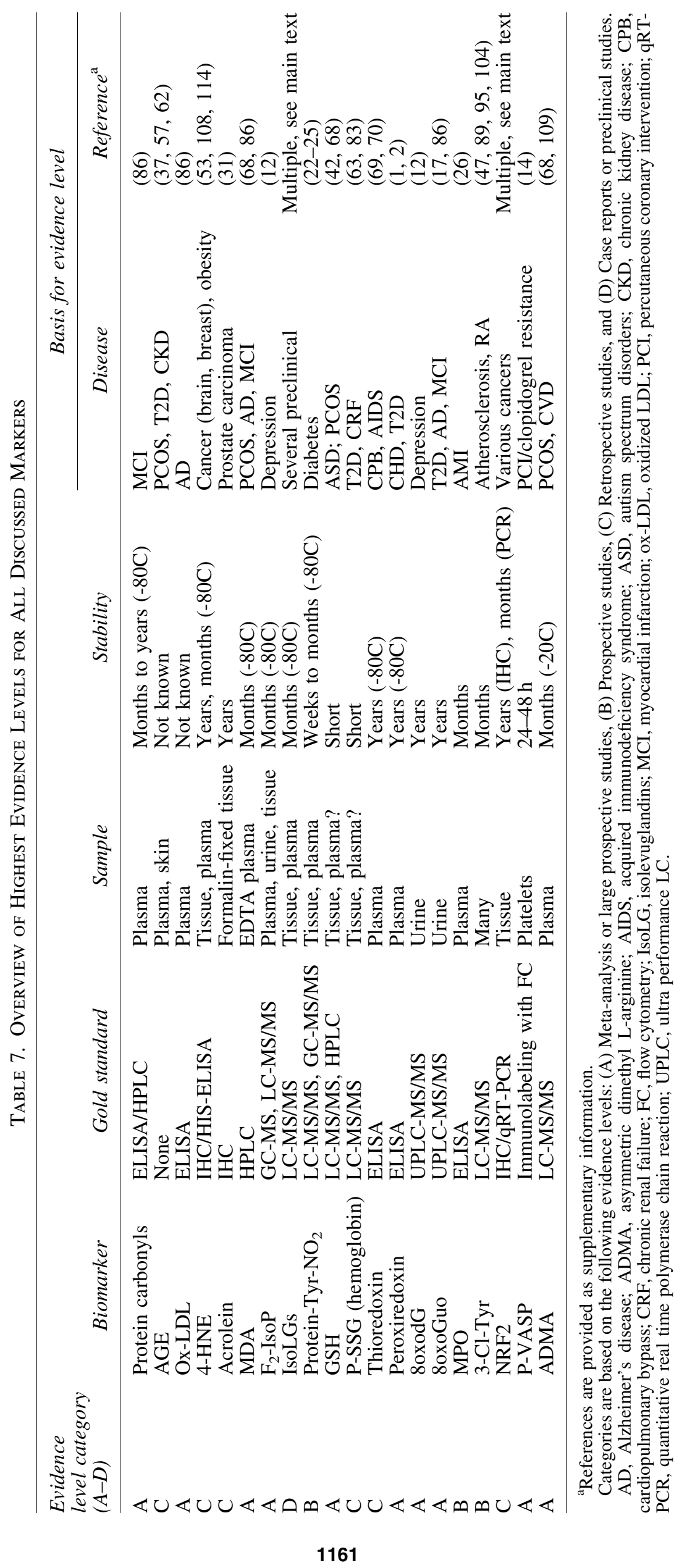


value of NRF2 has been reported for adenocarcinoma (79), squamous cell carcinoma (75), colon (84), lung (196), and breast cancer (129), among many others. NRF2 does not initiate carcinogenesis, but potentiates tumor promotion or metastasis. Somatic mutations in the NRF2 gene and in its repressor, KEAP1, have been found in a large percentage of human tumors, leading to constitutively increased NRF2 levels (68). Moreover, malignant transformation elicited by some oncogenes such as KRAS (42) or loss of tumor suppressor PTEN (142) leads to abnormally high levels of NRF2 protein and activity. Thus, analysis of NRF2 levels by either immunoblot or qRT-PCR in tumor biopsies is becoming a tool to clinically assess tumor malignancy.

NRF2 activity declines with age as well as in degenerative disorders. Considering that NRF2 is being validated as an antioxidant and immunomodulator target for diseases with an autoimmune component or with low-grade chronic inflammation, it will be necessary to develop reliable predictive markers that help to monitor effective targeting. The most significant advancement in development of these prospective biomarkers has been in patients with chronic obstructive pulmonary disorder. In a small cohort of these patients, it was reported that dietary administration of sulforaphane-rich broccoli sprout extract for two weeks enhanced the mRNA levels of several NRF2-regulated genes in peripheral blood mononuclear cells (67).

\section{Downstream Functional Markers of ROS-Induced Damage}

The biomarkers described above are indicative of increased ROS levels, either by increased formation or decreased removal. An alternative would be markers that reflect oxidative stress downstream of the ROS-induced damage. Ideally, this marker would be a direct risk factor so that its modulation by therapeutic interventions would predict a positive outcome. Two markers appear to qualify for this, asymmetric dimethyl L-arginine (ADMA) and phosphorylated vasodilator-stimulated phosphoprotein (P-VASP).

\section{Asymmetric dimethyl L-arginine}

ADMA is a ubiquitous metabolite derived from protein modification and degradation. Upon accumulation, it can interfere with arginine metabolism and ${ }^{\bullet} \mathrm{NO}$ formation by endothelial ${ }^{\bullet} \mathrm{NO}$ synthase (NOS) eNOS/NOS3 (182), and plasma ADMA concentrations correlate with endothelial, kidney, and erectile dysfunction (100), as well as heart failure (66). Plasma ADMA concentrations are significantly associated with every disease of the cardiovascular system, showing an independent, strong prognostic value for mortality and future cardiovascular events. However, non-CVDs with a possible deregulation of NOS have not been studied in great detail. ADMA is either excreted by cationic amino acid transporters that supply intracellular NOS with its substrate, L-arginine, and then eliminated by the kidney or metabolized to L-citrulline by $N^{G}-N^{G}$ dimethylarginine dimethylaminohydrolase (DDAH) (171). DDAH has an active site cysteine residue that can be a direct target of oxidative or nitrosative modification (99), resulting in the inhibition of ADMA degradation. Increased intracellular ADMA levels may be the reason for the observed therapeutic effects of L-arginine $(153,154)$ (see the accompanying ARS FORUM review on Therapeutics).

\section{Phosphorylated vasodilator-stimulated phosphoprotein}

The best-established marker for physiological cyclic guanosine monophosphate (cGMP) signaling is probably P-VASP. It is phosphorylated mainly by cGMP-dependent protein kinases (25), and lowered P-VASP levels are indicative of pathological signaling $(77,110)$. This pathological signaling can be brought about by oxidative stress, for example, through scavenging of ${ }^{\bullet} \mathrm{NO}$ by superoxide or direct oxidation of soluble guanylate cyclase (sGC), both of which limit the level of sGC activation and cGMP production (Fig. 2). However, in human blood samples, for example, in platelets, P-VASP levels can be utilized to establish the efficacy of (or detect nonresponders to) antiplatelet drugs (57), to detect physiological responses to NO donors and hence the presence of sGC (155), or to identify pathological responses to $\mathrm{sGC}$ activators as an indirect assay of increased oxidized/apo-sGC levels (2) (see the accompanying ARS Forum review on Targets).

\section{Conclusion}

The markers discussed here have been studied in different disease settings and with different rigor, ranging from metaanalyses of several clinical studies to promising evidence in preclinical studies (Table 7). However, even when the highest evidence level is available, their specificity as a biomarker of oxidative stress could be questionable, as in the case of oxLDL. Oxidative stress likely plays a role in several diseases, yet very few oxidative stress markers have made it into routine clinical use, which may have several reasons. The properties of the oxidative modifications, such as the labile nature of cysteine modifications, or their low abundance poses significant challenges to translate them into a high-throughput, cost-effective clinical diagnostic. Stable oxidative modifications, such as protein carbonyls, certain lipid oxidation products, DNA/RNA oxidation, and 3-nitrotyrosine, certainly circumvent the first issue, which likely contributes to some of their positive clinical findings. Another limitation is methodology. While MS provides sensitivity and specificity and has become more accessible, antibody-based methods remain, for now, the clinical standard. However, as we have seen, some of these methods fall short on specificity, such as antibodies specific for oxLDL, and any new antibody-based marker requires rigorous testing for specificity and sensitivity. Other antibody-based methods, such as immunohistochemistry, require tissues that are not commonly accessible. Circulating cell harvesting methods may provide a future solution to this. For a new biomarker to be established for clinical use, it would also require additional benefit over established clinical markers. Paradoxically, this additional value of oxidative stress biomarkers may come from being indicators of a disease mechanism common to several pathologies rather than diagnostic for a specific disease. Oxidative stress biomarkers may help in identifying patient populations that benefit from certain treatments, allowing patient stratification based on pathogenic mechanisms rather than just disease severity, thus responding to a specific request from regulatory agencies (47). On the other hand, protein-specific modifications such as nitrotyrosine could be disease-specific biomarkers of oxidative stress (Table 4).

\section{Outlook}

One way forward may be the analysis of oxidative stress markers for specific proteins. Such markers might better 
represent an underlying specific disease mechanism and a means for therapeutic monitoring and outcome prediction. In addition, as many of the markers have been measured in similar diseases, a combination of them in large-scale panels and pattern analysis could provide an additional approach to measure disease progression or therapeutic outcome (Fig. 3). This will help overcome the problem of the fragmentation of the literature in the field as different markers of oxidative stress are measured in different diseases. Measurement of larger panels of biomarkers in key conditions will help give a more comprehensive picture of their significance. In parallel with the exciting developments on ROS-validated targets and clinical indications, those markers and patterns that correlate best with treatment efficacy or mortality will eventually advance the field of ROS biomarkers, for example, in the form of theranostic couples of a new drug comarketed with a diagnostic marker.

\section{Acknowledgments}

The authors acknowledge financial support from the European Cooperation in Science and Technology (COST Action BM1203/EU-ROS) (P.G.W., N.Z., T.R., A.C., H.E.P., H.H.H.W.S., P.G.), the Peptide Research Network of Excellence, European Cross-border Cooperation Programme INTERREG IV A France (Channel)-England, ERDF (P.G.), the Toyota foundation, Denmark (H.E.P.), a Senior Principal Research Fellowship from the National Health and Medical Research Council and National Health and Medical Research Council Project Grants 1020776 and 1060804 (R.S.), and National Institutes of Health Grant HL116263 (S.S.D.). A.K. is supported by a grant from the Defence Science and Technology Laboratory, United Kingdom, to P.G.W. and E.L.T.

\section{References}

1. Abbasi A, Corpeleijn E, Gansevoort RT, Gans ROB, Struck J, Schulte J, Hillege HL, van der Harst P, Stolk RP, Navis G, and Bakker SJL. Circulating peroxiredoxin 4 and type 2 diabetes risk: the Prevention of Renal and Vascular Endstage Disease (PREVEND) study. Diabetologia 57: 1842-1849, 2014.

2. Ahrens I, Habersberger J, Baumlin N, Qian H, Smith BK, Stasch J-P, Bode C, Schmidt HHHW, and Peter K. Measuring oxidative burden and predicting pharmacological response in coronary artery disease patients with a novel direct activator of haem-free/oxidised sGC. Atherosclerosis 218: 431-434, 2011.

3. Alvarez B and Radi R. Peroxynitrite reactivity with amino acids and proteins. Amino Acids 25: 295-311, 2003.

4. Ames BN, Cathcart R, Schwiers E, and Hochstein P. Uric acid provides an antioxidant defense in humans against oxidant- and radical-caused aging and cancer: a hypothesis. Proc Natl Acad Sci U S A 78: 6858-6862, 1981.

5. Andresen M, Regueira T, Bruhn A, Perez D, Strobel P, Dougnac A, Marshall G, and Leighton F. Lipoperoxidation and protein oxidative damage exhibit different kinetics during septic shock. Mediators Inflamm 2008: 168652-168658, 2008.

6. Atkuri KR, Mantovani JJ, Herzenberg LA, and Herzenberg LA. N-Acetylcysteine-a safe antidote for cysteine/ glutathione deficiency. Curr Opin Pharmacol 7: 355-359, 2007.
7. Awad JA, Morrow JD, Takahashi K, and Roberts LJ. Identification of non-cyclooxygenase-derived prostanoid (F2-isoprostane) metabolites in human urine and plasma. $J$ Biol Chem 268: 4161-4169, 1993.

8. Baker AF, Dragovich T, Tate WR, Ramanathan RK, Roe D, Hsu C-H, Kirkpatrick DL, and Powis G. The antitumor thioredoxin-1 inhibitor PX-12 (1-methylpropyl 2-imidazolyl disulfide) decreases thioredoxin-1 and VEGF levels in cancer patient plasma. J Lab Clin Med 147: 83-90, 2006.

9. Baker JR, Metcalf PA, Johnson RN, Newman D, and Rietz P. Use of protein-based standards in automated colorimetric determinations of fructosamine in serum. Clin Chem 31: 1550-1554, 1985.

10. Barregard L, Møller P, Henriksen T, Mistry V, Koppen G, Rossner P, Sram RJ, Weimann A, Poulsen HE, Nataf R, Andreoli R, Manini P, Marczylo T, Lam P, Evans MD, Kasai H, Kawai K, Li Y-S, Sakai K, Singh R, Teichert F, Farmer PB, Rozalski R, Gackowski D, Siomek A, Saez GT, Cerda C, Broberg K, Lindh C, Hossain MB, Haghdoost S, Hu C-W, Chao M-R, Wu K-Y, Orhan H, Senduran N, Smith RJ, Santella RM, Su Y, Cortez C, Yeh S, Olinski R, Loft S, and Cooke MS. Human and methodological sources of variability in the measurement of urinary 8-oxo-7,8-dihydro-2'-deoxyguanosine. Antioxid Redox Signal 18: 2377-2391, 2013.

11. Bartesaghi S, Ferrer-Sueta G, Peluffo G, Valez V, Zhang $\mathrm{H}$, Kalyanaraman B, and Radi R. Protein tyrosine nitration in hydrophilic and hydrophobic environments. Amino Acids 32: 501-515, 2006.

12. Battelli MG, Bolognesi A, and Polito L. Pathophysiology of circulating xanthine oxidoreductase: new emerging roles for a multi-tasking enzyme. Biochim Biophys Acta 1842: 1502-1517, 2014.

13. Bayer SB, Maghzal G, Stocker R, Hampton MB, and Winterbourn CC. Neutrophil-mediated oxidation of erythrocyte peroxiredoxin 2 as a potential marker of oxidative stress in inflammation. FASEB J 27: 3315-3322, 2013.

14. Bäck M and Hansson GK. Anti-inflammatory therapies for atherosclerosis. Nat Rev Cardiol 12: 199-211, 2015.

15. Bergt C, Pennathur S, Fu X, Byun J, O'Brien K, McDonald TO, Singh P, Anantharamaiah GM, Chait A, Brunzell J, Geary RL, Oram JF, and Heinecke JW. The myeloperoxidase product hypochlorous acid oxidizes HDL in the human artery wall and impairs ABCA1-dependent cholesterol transport. Proc Natl Acad Sci U S A 101: 13032-13037, 2004.

16. Bowry VW, Stanley KK, and Stocker R. High density lipoprotein is the major carrier of lipid hydroperoxides in human blood plasma from fasting donors. Proc Natl Acad Sci U S A 89: 10316-10320, 1992.

17. Brame CJ, Boutaud O, Davies SS, Yang T, Oates JA, Roden D, and Roberts LJ. Modification of proteins by isoketal-containing oxidized phospholipids. J Biol Chem 279: 13447-13451, 2004.

18. Brame CJ, Salomon RG, Morrow JD, and Roberts LJ. Identification of extremely reactive gamma-ketoaldehydes (isolevuglandins) as products of the isoprostane pathway and characterization of their lysyl protein adducts. $J$ Biol Chem 274: 13139-13146, 1999.

19. Breusing N, Grune T, Andrisic L, Atalay M, Bartosz G, Biasi F, Borovic S, Bravo L, Casals I, Casillas R, Dinischiotu A, Drzewinska J, Faber H, Fauzi NM, Gajewska A, Gambini J, Gradinaru D, Kokkola T, Lojek A, Luczaj W, Margina D, Mascia C, Mateos R, Meinitzer A, 
Mitjavila MT, Mrakovcic L, Munteanu MC, Podborska M, Poli G, Sicinska P, Skrzydlewska E, Vina J, Wiswedel I, Zarkovic N, Zelzer S, and Spickett CM. An interlaboratory validation of methods of lipid peroxidation measurement in UVA-treated human plasma samples. Free Radic Res 44: 1203-1215, 2010.

20. Brix JM, Höllerl F, Kopp H-P, Schernthaner GH, and Schernthaner G. The soluble form of the receptor of advanced glycation endproducts increases after bariatric surgery in morbid obesity. Int J Obes (Lond) 36: 14121417, 2012.

21. Brock JWC, Jenkins AJ, Lyons TJ, Klein RL, Yim E, Lopes-Virella M, Carter RE, (DCCT/EDIC) Research Group, Thorpe SR, and Baynes JW. Increased methionine sulfoxide content of apoA-I in type 1 diabetes. J Lipid Res 49: 847-855, 2008.

22. Broedbaek K, Siersma V, Henriksen T, Weimann A, Petersen M, Andersen JT, Jimenez-Solem E, Hansen LJ, Henriksen JE, Bonnema SJ, de Fine Olivarius N, Friis S, and Poulsen HE. Urinary markers of nucleic acid oxidation and cancer in type 2 diabetes. Redox Biol 4C: 34-39, 2014.

23. Broedbaek K, Siersma V, Henriksen T, Weimann A, Petersen M, Andersen JT, Jimenez-Solem E, Stovgaard ES, Hansen LJ, Henriksen JE, Bonnema SJ, Olivarius Nde F, and Poulsen HE. Urinary markers of nucleic acid oxidation and long-term mortality of newly diagnosed type 2 diabetic patients. Diabetes Care 34: 2594-2596, 2011.

24. Buss H, Chan TP, Sluis KB, Domigan NM, and Winterbourn CC. Protein carbonyl measurement by a sensitive ELISA method. Free Radic Biol Med 23: 361-366, 1997.

25. Butler R, Morris AD, Belch JJ, Hill A, and Struthers AD. Allopurinol normalizes endothelial dysfunction in type 2 diabetics with mild hypertension. Hypertension 35: 746$751,2000$.

26. Calabretta A, Küpfer PA, and Leumann CJ. The effect of RNA base lesions on mRNA translation. Nucleic Acids Res 43: 4713-4720, 2015.

27. Carp H, Miller F, Hoidal JR, and Janoff A. Potential mechanism of emphysema: alpha 1-proteinase inhibitor recovered from lungs of cigarette smokers contains oxidized methionine and has decreased elastase inhibitory capacity. Proc Natl Acad Sci U S A 79: 2041-2045, 1982.

28. Ceriello A, Esposito K, Piconi L, Ihnat M, Thorpe J, Testa R, Bonfigli AR, and Giugliano D. Glucose "peak" and glucose "spike": impact on endothelial function and oxidative stress. Diabetes Res Clin Pract 82: 262-267, 2008.

29. Ceriello A, Kumar S, Piconi L, Esposito K, and Giugliano D. Simultaneous control of hyperglycemia and oxidative stress normalizes endothelial function in type 1 diabetes. Diabetes Care 30: 649-654, 2007.

30. Checconi P, Salzano S, Bowler L, Mullen L, Mengozzi M, Hanschmann E-M, Lillig CH, Sgarbanti R, Panella S, Nencioni L, Palamara AT, and Ghezzi P. Redox proteomics of the inflammatory secretome identifies a common set of redoxins and other glutathionylated proteins released in inflammation, influenza virus infection and oxidative stress. PLoS One 10: e0127086, 2015.

31. Chen H-JC, Lin W-P, Chiu S-D, and Fan C-H. Multistage mass spectrometric analysis of human hemoglobin glutathionylation: correlation with cigarette smoking. Chem Res Toxicol 27: 864-872, 2014.

32. Choi D-K, Pennathur S, Perier C, Tieu K, Teismann P, Wu D-C, Jackson-Lewis V, Vila M, Vonsattel J-P, Hei- necke JW, and Przedborski S. Ablation of the inflammatory enzyme myeloperoxidase mitigates features of Parkinson's disease in mice. J Neurosci 25: 6594-6600, 2005.

33. Dalle-Donne I, Rossi R, Colombo R, Giustarini D, and Milzani A. Biomarkers of oxidative damage in human disease. Clin Chem 52: 601-623, 2006.

34. Dalle-Donne I, Rossi R, Giustarini D, Milzani A, and Colombo R. Protein carbonyl groups as biomarkers of oxidative stress. Clin Chim Acta 329: 23-38, 2003.

35. Daugherty A, Dunn JL, Rateri DL, and Heinecke JW. Myeloperoxidase, a catalyst for lipoprotein oxidation, is expressed in human atherosclerotic lesions. J Clin Invest 94: 437-444, 1994.

36. Davies SS, Amarnath V, Montine KS, Bernoud-Hubac N, Boutaud O, Montine TJ, and Roberts LJ. Effects of reactive gamma-ketoaldehydes formed by the isoprostane pathway (isoketals) and cyclooxygenase pathway (levuglandins) on proteasome function. FASEB $J$ 16: 715717, 2002.

37. Davies SS, Amarnath V, and Roberts LJ. Isoketals: highly reactive gamma-ketoaldehydes formed from the $\mathrm{H} 2-$ isoprostane pathway. Chem Phys Lipids 128: 85-99, 2004.

38. Davies SS, Bodine C, Matafonova E, Pantazides BG, Bernoud-Hubac N, Harrison FE, Olson SJ, Montine TJ, Amarnath V, and Roberts LJ. Treatment with a $\gamma$ ketoaldehyde scavenger prevents working memory deficits in hApoE4 mice. J Alzheimers Dis 27: 49-59, 2011.

39. Davies SS and Roberts LJ. F2-isoprostanes as an indicator and risk factor for coronary heart disease. Free Radic Biol Med 50: 559-566, 2011.

40. Dean RT, Fu S, Stocker R, and Davies MJ. Biochemistry and pathology of radical-mediated protein oxidation. Biochem J 324 (Pt 1): 1-18, 1997.

41. Degenhardt TP, Alderson NL, Arrington DD, Beattie RJ, Basgen JM, Steffes MW, Thorpe SR, and Baynes JW. Pyridoxamine inhibits early renal disease and dyslipidemia in the streptozotocin-diabetic rat. Kidney Int 61: 939950, 2002.

42. DeNicola GM, Karreth FA, Humpton TJ, Gopinathan A, Wei C, Frese K, Mangal D, Yu KH, Yeo CJ, Calhoun ES, Scrimieri F, Winter JM, Hruban RH, Iacobuzio-Donahue C, Kern SE, Blair IA, and Tuveson DA. Oncogeneinduced Nrf2 transcription promotes ROS detoxification and tumorigenesis. Nature 475: 106-109, 2011.

43. Di Giuseppe D, Di Simplicio P, Capecchi PL, Lazzerini PE, and Pasini FL. Alteration in the redox state of plasma in heart-transplant patients with moderate hyperhomocysteinemia. J Lab Clin Med 142: 21-28, 2003.

44. Dildar K, Sinem F, Gökhan E, Orhan Y, and Filiz M. Serum nitrosative stress levels are increased in Alzheimer disease but not in vascular dementia. Alzheimer Dis Assoc Disord 24: 194-197, 2010.

45. Duncan MW. A review of approaches to the analysis of 3nitrotyrosine. Amino Acids 25: 351-361, 2003.

46. Eck HP, Gmünder H, Hartmann M, Petzoldt D, Daniel V, and Dröge W. Low concentrations of acid-soluble thiol (cysteine) in the blood plasma of HIV-1-infected patients. Biol Chem Hoppe Seyler 370: 101-108, 1989.

47. EFSA Panel on Dietetic Products, Nutrition and Allergies (NDA). Guidance on the scientific requirements for health claims related to antioxidants, oxidative damage and cardiovascular health. EFSA J 9: 2474-2486, 2011.

48. Enroth C, Eger BT, Okamoto K, Nishino T, and Pai EF. Crystal structures of bovine milk xanthine dehydrogenase 
and xanthine oxidase: structure-based mechanism of conversion. Proc Natl Acad Sci U S A 97: 10723-10728, 2000.

49. Esterbauer H, Schaur RJ, and Zollner H. Chemistry and biochemistry of 4-hydroxynonenal, malonaldehyde and related aldehydes. Free Radic Biol Med 11: 81-128, 1991.

50. Foster DB, Van Eyk JE, Marbán E, and O'Rourke B. Redox signaling and protein phosphorylation in mitochondria: progress and prospects. J Bioenerg Biomembr 41: 159-168, 2009.

51. Friedman P, Horkko S, Steinberg D, Witztum JL, and Dennis EA. Correlation of antiphospholipid antibody recognition with the structure of synthetic oxidized phospholipids. Importance of Schiff base formation and aldol condensation. J Biol Chem 277: 7010-7020, 2002.

52. Friess U, Waldner M, Wahl HG, Lehmann R, Haring HU, Voelter W, and Schleicher E. Liquid chromatographybased determination of urinary free and total N(epsilon)(carboxymethyl)lysine excretion in normal and diabetic subjects. J Chromatogr B Analyt Technol Biomed Life Sci 794: 273-280, 2003.

53. Frijhoff J, Dagnell M, Godfrey R, and Ostman A. Regulation of protein tyrosine phosphatase oxidation in cell adhesion and migration. Antioxid Redox Signal 20: 19942010, 2014.

54. Frustaci A, Neri M, Cesario A, Adams JB, Domenici E, Dalla Bernardina $\mathrm{B}$, and Bonassi S. Oxidative stressrelated biomarkers in autism: systematic review and metaanalyses. Free Radic Biol Med 52: 2128-2141, 2012.

55. Fu MX, Requena JR, Jenkins AJ, Lyons TJ, Baynes JW, and Thorpe SR. The advanced glycation end product, Nepsilon-(carboxymethyl)lysine, is a product of both lipid peroxidation and glycoxidation reactions. $\mathrm{J}$ Biol Chem 271: 9982-9986, 1996.

56. Fukuda K, Davies SS, Nakajima T, Ong B-H, Kupershmidt S, Fessel J, Amarnath V, Anderson ME, Boyden PA, Viswanathan PC, Roberts LJ, and Balser JR. Oxidative mediated lipid peroxidation recapitulates proarrhythmic effects on cardiac sodium channels. Circ Res 97: 1262-1269, 2005.

57. Geiger J, Teichmann L, Grossmann R, Aktas B, Steigerwald U, Walter U, and Schinzel R. Monitoring of clopidogrel action: comparison of methods. Clin Chem 51: 957-965, 2005.

58. Ghezzi P. Protein glutathionylation in health and disease. Biochim Biophys Acta 1830: 3165-3172, 2013.

59. Ghezzi P, Bianchi M, Mantovani A, Spreafico F, and Salmona M. Enhanced xanthine oxidase activity in mice treated with interferon and interferon inducers. Biochem Biophys Res Commun 119: 144-149, 1984.

60. Giasson BI, Duda JE, Murray IV, Chen Q, Souza JM, Hurtig HI, Ischiropoulos H, Trojanowski JQ, and Lee VM. Oxidative damage linked to neurodegeneration by selective alpha-synuclein nitration in synucleinopathy lesions. Science 290: 985-989, 2000.

61. Gil L, Siems W, Mazurek B, Gross J, Schroeder P, Voss P, and Grune T. Age-associated analysis of oxidative stress parameters in human plasma and erythrocytes. Free Radic Res 40: 495-505, 2006.

62. Greilberger J, Koidl C, Greilberger M, Lamprecht M, Schroecksnadel K, Leblhuber F, Fuchs D, and Oettl K. Malondialdehyde, carbonyl proteins and albumindisulphide as useful oxidative markers in mild cognitive impairment and Alzheimer's disease. Free Radic Res 42: 633-638, 2008.
63. Guéraud F, Taché S, Steghens J-P, Milkovic L, BorovicSunjic S, Zarkovic N, Gaultier E, Naud N, HélièsToussaint C, Pierre F, and Priymenko N. Dietary polyunsaturated fatty acids and heme iron induce oxidative stress biomarkers and a cancer promoting environment in the colon of rats. Free Radic Biol Med 83: 192-200, 2015.

64. Guo L, Amarnath V, and Davies SS. A liquid chromatography-tandem mass spectrometry method for measurement of $\mathrm{N}$-modified phosphatidylethanolamines. Anal Biochem 405: 236-245, 2010.

65. Guo L, Chen Z, Cox BE, Amarnath V, Epand RF, Epand RM, and Davies SS. Phosphatidylethanolamines modified by $\gamma$-ketoaldehyde ( $\gamma \mathrm{KA})$ induce endoplasmic reticulum stress and endothelial activation. J Biol Chem 286: 1817018180, 2011.

66. Haehling von S, Bode-Böger SM, Martens-Lobenhoffer J, Rauchhaus M, Schefold JC, Genth-Zotz S, Karhausen T, Cicoira M, Anker SD, and Doehner W. Elevated levels of asymmetric dimethylarginine in chronic heart failure: a pathophysiologic link between oxygen radical load and impaired vasodilator capacity and the therapeutic effect of allopurinol. Clin Pharmacol Ther 88: 506-512, 2010.

67. Harvey CJ, Thimmulappa RK, Sethi S, Kong X, Yarmus L, Brown RH, Feller-Kopman D, Wise R, and Biswal S. Targeting Nrf2 signaling improves bacterial clearance by alveolar macrophages in patients with COPD and in a mouse model. Sci Transl Med 3: 78ra32, 2011.

68. Hayes JD and McMahon M. NRF2 and KEAP1 mutations: permanent activation of an adaptive response in cancer. Trends Biochem Sci 34: 176-188, 2009.

69. This reference has been deleted.

70. Henderson PT, Evans MD, and Cooke MS. Salvage of oxidized guanine derivatives in the $\left(2^{\prime}\right.$-deoxy)ribonucleotide pool as source of mutations in DNA. Mutat Res 703: 11-17, 2010

71. Herce-Pagliai C, Kotecha S, and Shuker DE. Analytical methods for 3-nitrotyrosine as a marker of exposure to reactive nitrogen species: a review. Nitric Oxide 2: 324 336, 1998.

72. Herzenberg LA, Parks D, Sahaf B, Perez O, Roederer M, and Herzenberg LA. The history and future of the fluorescence activated cell sorter and flow cytometry: a view from Stanford. Clin Chem 48: 1819-1827, 2002.

73. Holvoet P, Donck J, Landeloos M, Brouwers E, Luijtens K, Arnout J, Lesaffre E, Vanrenterghem Y, and Collen D. Correlation between oxidized low density lipoproteins and von Willebrand factor in chronic renal failure. Thromb Haemost 76: 663-669, 1996.

74. Hool LC and Corry B. Redox control of calcium channels: from mechanisms to therapeutic opportunities. Antioxid Redox Signal 9: 409-435, 2007.

75. Huang C-F, Zhang L, Ma S-R, Zhao Z-L, Wang W-M, He K-F, Zhao Y-F, Zhang W-F, Liu B, and Sun Z-J. Clinical significance of Keap1 and Nrf2 in oral squamous cell carcinoma. PLoS One 8: e83479, 2013.

76. Hwang C, Sinskey AJ, and Lodish HF. Oxidized redox state of glutathione in the endoplasmic reticulum. Science 257: 1496-1502, 1992.

77. Ibarra-Alvarado C, Galle J, Melichar VO, Mameghani A, and Schmidt HHHW. Phosphorylation of blood vessel vasodilator-stimulated phosphoprotein at serine 239 as a functional biochemical marker of endothelial nitric oxide/ cyclic GMP signaling. Mol Pharmacol 61: 312-319, 2002. 
78. Il'yasova D, Morrow JD, Ivanova A, and Wagenknecht LE. Epidemiological marker for oxidant status: comparison of the ELISA and the gas chromatography/mass spectrometry assay for urine 2,3-dinor-5,6-dihydro-15F2t-isoprostane. Ann Epidemiol 14: 793-797, 2004.

79. Inoue D, Suzuki T, Mitsuishi Y, Miki Y, Suzuki S, Sugawara S, Watanabe M, Sakurada A, Endo C, Uruno A, Sasano H, Nakagawa T, Satoh K, Tanaka N, Kubo H, Motohashi H, and Yamamoto M. Accumulation of p62/ SQSTM1 is associated with poor prognosis in patients with lung adenocarcinoma. Cancer Sci 103: 760-766, 2012.

80. Ishii T, Warabi E, and Yanagawa T. Novel roles of peroxiredoxins in inflammation, cancer and innate immunity. J Clin Biochem Nutr 50: 91-105, 2012.

81. Itabe $\mathrm{H}$ and Ueda $\mathrm{M}$. Measurement of plasma oxidized low-density lipoprotein and its clinical implications. $J$ Atheroscler Thromb 14: 1-11, 2007.

82. Itabe H, Yamamoto H, Suzuki M, Kawai Y, Nakagawa Y, Suzuki A, Imanaka T, and Takano T. Oxidized phosphatidylcholines that modify proteins. Analysis by monoclonal antibody against oxidized low density lipoprotein. $J$ Biol Chem 271: 33208-33217, 1996.

83. Janssen-Heininger YMW, Mossman BT, Heintz NH, Forman HJ, Kalyanaraman B, Finkel T, Stamler JS, Rhee SG, and van der Vliet A. Redox-based regulation of signal transduction: principles, pitfalls, and promises. Free Radic Biol Med 45: 1-17, 2008.

84. Ji L, Wei Y, Jiang T, and Wang S. Correlation of Nrf2, NQO1, MRP1, cmyc and p53 in colorectal cancer and their relationships to clinicopathologic features and survival. Int J Clin Exp Pathol 7: 1124-1131, 2014.

85. Johnson D and Travis J. The oxidative inactivation of human alpha-1-proteinase inhibitor. Further evidence for methionine at the reactive center. J Biol Chem 254: 40224026, 1979.

86. Jones DP, Carlson JL, Mody VC, Cai J, Lynn MJ, and Sternberg P. Redox state of glutathione in human plasma. Free Radic Biol Med 28: 625-635, 2000.

87. Jones DP and Go Y-M. Mapping the cysteine proteome: analysis of redox-sensing thiols. Curr Opin Chem Biol 15: 103-112, 2011.

88. Jorgensen A, Broedbaek K, Fink-Jensen A, Knorr U, Greisen Soendergaard M, Henriksen T, Weimann A, Jepsen P, Lykkesfeldt J, Poulsen HE, and Balslev Jorgensen M. Increased systemic oxidatively generated DNA and RNA damage in schizophrenia. Psychiatry Res 209: 417-423, 2013.

89. Kadiiska MB, Gladen BC, Baird DD, Germolec D, Graham LB, Parker CE, Nyska A, Wachsman JT, Ames BN, Basu S, Brot N, Fitzgerald GA, Floyd RA, George M, Heinecke JW, Hatch GE, Hensley K, Lawson JA, Marnett LJ, Morrow JD, Murray DM, Plastaras J, Roberts LJ, Rokach J, Shigenaga MK, Sohal RS, Sun J, Tice RR, Van Thiel DH, Wellner D, Walter PB, Tomer KB, Mason RP, and Barrett JC. Biomarkers of oxidative stress study II: are oxidation products of lipids, proteins, and DNA markers of CCl4 poisoning? Free Radic Biol Med 38: 698-710, 2005.

90. Kaplowitz N, Fernández-Checa JC, Kannan R, GarciaRuiz C, Ookhtens M, and Yi JR. GSH transporters: molecular characterization and role in GSH homeostasis. Biol Chem Hoppe Seyler 377: 267-273, 1996.

91. Keller RJ, Halmes NC, Hinson JA, and Pumford NR. Immunochemical detection of oxidized proteins. Chem Res Toxicol 6: 430-433, 1993.
92. Kettle AJ, Albrett AM, Chapman AL, Dickerhof N, Forbes LV, Khalilova I, and Turner R. Measuring chlorine bleach in biology and medicine. Biochim Biophys Acta 1840: 781-793, 2014.

93. Kettle AJ, Chan T, Osberg I, Senthilmohan R, Chapman ALP, Mocatta TJ, and Wagener JS. Myeloperoxidase and protein oxidation in the airways of young children with cystic fibrosis. Am J Respir Crit Care Med 170: 13171323, 2004.

94. Khan J, Brennand D, Bradley N, Gao B, Bruckdorfer R, and Jacobs M. 3-Nitrotyrosine in the proteins of human plasma determined by an ELISA method. Biochem $J 332$ (Pt 3): 807-808, 1998.

95. Kirabo A, Fontana V, de Faria APC, Loperena R, Galindo CL, Wu J, Bikineyeva AT, Dikalov S, Xiao L, Chen W, Saleh MA, Trott DW, Itani HA, Vinh A, Amarnath V, Amarnath K, Guzik TJ, Bernstein KE, Shen XZ, Shyr Y, Chen S-C, Mernaugh RL, Laffer CL, Elijovich F, Davies SS, Moreno H, Madhur MS, Roberts J, and Harrison DG. DC isoketal-modified proteins activate $\mathrm{T}$ cells and promote hypertension. J Clin Invest 124: 4642-4656, 2014.

96. Kondo N, Ishii Y, Kwon Y-W, Tanito M, Horita H, Nishinaka Y, Nakamura H, and Yodoi J. Redox-sensing release of human thioredoxin from $\mathrm{T}$ lymphocytes with negative feedback loops. J Immunol 172: 442-448, 2004.

97. Kunert C, Skurk T, Frank O, Lang R, Hauner H, and Hofmann T. Development and application of a stable isotope dilution analysis for the quantitation of advanced glycation end products of creatinine in biofluids of type 2 diabetic patients and healthy volunteers. Anal Chem 85: 2961-2969, 2013.

98. Laragione T, Gianazza E, Tonelli R, Bigini P, Mennini T, Casoni F, Massignan T, Bonetto V, and Ghezzi P. Regulation of redox-sensitive exofacial protein thiols in $\mathrm{CHO}$ cells. Biol Chem 387: 1371-1376, 2006.

99. Leiper J, Murray-Rust J, McDonald N, and Vallance P. Snitrosylation of dimethylarginine dimethylaminohydrolase regulates enzyme activity: further interactions between nitric oxide synthase and dimethylarginine dimethylaminohydrolase. Proc Natl Acad Sci U S A 99: 13527-13532, 2002.

100. Leiper $\mathbf{J}$ and Nandi $M$. The therapeutic potential of targeting endogenous inhibitors of nitric oxide synthesis. Nat Rev Drug Discov 10: 277-291, 2011.

101. Levine RL, Garland D, Oliver CN, Amici A, Climent I, Lenz AG, Ahn BW, Shaltiel S, and Stadtman ER. Determination of carbonyl content in oxidatively modified proteins. Methods Enzymol 186: 464-478, 1990.

102. Li W, Laird JM, Lu L, Roychowdhury S, Nagy LE, Zhou $\mathrm{R}$, Crabb JW, and Salomon RG. Isolevuglandins covalently modify phosphatidylethanolamines in vivo: detection and quantitative analysis of hydroxylactam adducts. Free Radic Biol Med 47: 1539-1552, 2009.

103. Loft S, Olsen A, Møller P, Poulsen HE, and Tjønneland A. Association between 8-oxo-7,8-dihydro-2'-deoxyguanosine excretion and risk of postmenopausal breast cancer: nested case-control study. Cancer Epidemiol Biomarkers Prev 22: 1289-1296, 2013.

104. Loft S and Poulsen HE. Markers of oxidative damage to DNA: antioxidants and molecular damage. Methods Enzymol 300: 166-184, 1999.

105. Loft S, Svoboda P, Kawai K, Kasai H, Sørensen M, Tjønneland A, Vogel U, Møller P, Overvad K, and RaaschouNielsen O. Association between 8-oxo-7,8-dihydroguanine 
excretion and risk of lung cancer in a prospective study. Free Radic Biol Med 52: 167-172, 2012.

106. Manevich Y, Hutchens S, Halushka PV, Tew KD, Townsend DM, Jauch EC, and Borg K. Peroxiredoxin VI oxidation in cerebrospinal fluid correlates with traumatic brain injury outcome. Free Radic Biol Med 72: 210-221, 2014.

107. Martinon F, Pétrilli V, Mayor A, Tardivel A, and Tschopp J. Gout-associated uric acid crystals activate the NALP3 inflammasome. Nature 440: 237-241, 2006.

108. McCord JM. Oxygen-derived free radicals in postischemic tissue injury. N Engl J Med 312: 159-163, 1985.

109. McCord JM and Fridovich I. The reduction of cytochrome c by milk xanthine oxidase. J Biol Chem 243: 5753-5760, 1968.

110. Melichar VO, Behr-Roussel D, Zabel U, Uttenthal LO, Rodrigo J, Rupin A, Verbeuren TJ, Kumar H S A, and Schmidt HHHW. Reduced cGMP signaling associated with neointimal proliferation and vascular dysfunction in late-stage atherosclerosis. Proc Natl Acad Sci U S A 101: 16671-16676, 2004.

111. Mengozzi M, Ermilov P, Annenkov A, Ghezzi P, and Pearl F. Definition of a family of tissue-protective cytokines using functional cluster analysis: a proof-of-concept study. Front Immunol 5: 115, 2014.

111a. Mihm MJ, Jing L, Bauer JA. Nitrotyrosine causes selective vascular endothelial dysfunction and DNA damage. $J$ Cardiovasc Pharmacol 36: 182-187, 2000.

112. Mills BJ, Weiss MM, Lang CA, Liu MC, and Ziegler C. Blood glutathione and cysteine changes in cardiovascular disease. J Lab Clin Med 135: 396-401, 2000.

113. Milne GL, Dai Q, and Roberts LJ. The isoprostanes-25 years later. Biochim Biophys Acta 1851: 433-445, 2014.

114. Milne GL, Sanchez SC, Musiek ES, and Morrow JD. Quantification of F2-isoprostanes as a biomarker of oxidative stress. Nat Protoc 2: 221-226, 2007.

115. Milne GL, Yin H, Hardy KD, Davies SS, and Roberts LJ. Isoprostane generation and function. Chem Rev 111: 5973-5996, 2011.

116. Miyata T, Ueda Y, Shinzato T, Iida Y, Tanaka S, Kurokawa K, van Ypersele de Strihou C, and Maeda K. Accumulation of albumin-linked and free-form pentosidine in the circulation of uremic patients with end-stage renal failure: renal implications in the pathophysiology of pentosidine. J Am Soc Nephrol 7: 1198-1206, 1996.

117. Moore K and Roberts LJ. Measurement of lipid peroxidation. Free Radic Res 28: 659-671, 1998.

118. Moriarty-Craige SE and Jones DP. Extracellular thiols and thiol/disulfide redox in metabolism. Annu Rev Nutr 24: 481-509, 2004.

119. Morrow JD, Hill KE, Burk RF, Nammour TM, Badr KF, and Roberts LJ. A series of prostaglandin F2-like compounds are produced in vivo in humans by a noncyclooxygenase, free radical-catalyzed mechanism. Proc Natl Acad Sci U S A 87: 9383-9387, 1990.

120. Morrow JD, Roberts LJ, Daniel VC, Awad JA, Mirochnitchenko O, Swift LL, and Burk RF. Comparison of formation of D2/E2-isoprostanes and F2-isoprostanes in vitro and in vivo-effects of oxygen tension and glutathione. Arch Biochem Biophys 353: 160-171, 1998.

121. Murri M, Luque-Ramírez M, Insenser M, Ojeda-Ojeda M, and Escobar-Morreale HF. Circulating markers of oxidative stress and polycystic ovary syndrome (PCOS): a systematic review and meta-analysis. Hum Reprod Update 19: 268-288, 2013.
122. Mutlu-Türkoğlu U, Ilhan E, Oztezcan S, Kuru A, AykaçToker G, and Uysal M. Age-related increases in plasma malondialdehyde and protein carbonyl levels and lymphocyte DNA damage in elderly subjects. Clin Biochem 36: 397-400, 2003.

123. Nagra RM, Becher B, Tourtellotte WW, Antel JP, Gold D, Paladino T, Smith RA, Nelson JR, and Reynolds WF. Immunohistochemical and genetic evidence of myeloperoxidase involvement in multiple sclerosis. $J \mathrm{Neu}$ roimmunol 78: 97-107, 1997.

124. Nagumo K, Tanaka M, Chuang VTG, Setoyama H, Watanabe H, Yamada N, Kubota K, Tanaka M, Matsushita K, Yoshida A, Jinnouchi H, Anraku M, Kadowaki D, Ishima Y, Sasaki Y, Otagiri M, and Maruyama T. Cys34-cysteinylated human serum albumin is a sensitive plasma marker in oxidative stress-related chronic diseases. PLoS One 9: e85216, 2014.

125. Nakamura H, De Rosa SC, Yodoi J, Holmgren A, Ghezzi P, Herzenberg LA, and Herzenberg LA. Chronic elevation of plasma thioredoxin: inhibition of chemotaxis and curtailment of life expectancy in AIDS. Proc Natl Acad Sci U S A 98: 2688-2693, 2001.

126. Negre-Salvayre A, Auge N, Ayala V, Basaga H, Boada J, Brenke R, Chapple S, Cohen G, Feher J, Grune T, Lengyel G, Mann GE, Pamplona R, Poli G, Portero-Otin M, Riahi Y, Salvayre R, Sasson S, Serrano J, Shamni O, Siems W, Siow RCM, Wiswedel I, Zarkovic K, and Zarkovic N. Pathological aspects of lipid peroxidation. Free Radic Res 44: 1125-1171, 2010.

127. Ng F, Berk M, Dean O, and Bush AI. Oxidative stress in psychiatric disorders: evidence base and therapeutic implications. Int J Neuropsychopharmacol 11: 851-876, 2008.

128. This reference has been deleted.

129. Onodera Y, Motohashi H, Takagi K, Miki Y, Shibahara Y, Watanabe M, Ishida T, Hirakawa H, Sasano H, Yamamoto M, and Suzuki T. NRF2 immunolocalization in human breast cancer patients as a prognostic factor. Endocr Relat Cancer 21: 241-252, 2014.

130. Pantke U, Volk T, Schmutzler M, Kox WJ, Sitte N, and Grune T. Oxidized proteins as a marker of oxidative stress during coronary heart surgery. Free Radic Biol Med 27: 1080-1086, 1999.

131. Pedersen-Lane JH, Zurier RB, and Lawrence DA. Analysis of the thiol status of peripheral blood leukocytes in rheumatoid arthritis patients. J Leukoc Biol 81: 934-941, 2007.

132. Peluffo $G$ and Radi R. Biochemistry of protein tyrosine nitration in cardiovascular pathology. Cardiovasc Res 75: 291-302, 2007.

133. Poulsen HE, Nadal LL, Broedbaek K, Nielsen PE, and Weimann A. Detection and interpretation of 8-oxodG and 8-oxoGua in urine, plasma and cerebrospinal fluid. Biochim Biophys Acta 1840: 801-808, 2014.

134. Poulsen HE, Prieme H, and Loft S. Role of oxidative DNA damage in cancer initiation and promotion. Eur $J$ Cancer Prev 7: 9-16, 1998.

135. Poulsen HE, Specht E, Broedbaek K, Henriksen T, Ellervik C, Mandrup-Poulsen T, Tonnesen M, Nielsen PE, Andersen HU, and Weimann A. RNA modifications by oxidation: a novel disease mechanism? Free Radic Biol Med 52: 1353-1361, 2012.

135a. Proudfoot JM, Barden AE, Loke WM, Croft KD, Puddey IB, Mori TA. HDL is the major lipoprotein carrier of plasma F2-isoprostanes. J Lipid Res 50: 716-722, 2009.

136. Proudfoot J, Barden A, Mori TA, Burke V, Croft KD, Beilin LJ, and Puddey IB. Measurement of urinary F(2)- 
isoprostanes as markers of in vivo lipid peroxidation-A comparison of enzyme immunoassay with gas chromatography/mass spectrometry. Anal Biochem 272: 209-215, 1999.

137. Qi A-Q, Li Y, Liu Q, Si J-Z, Tang X-M, Zhang Z-Q, Qi $\mathrm{Q}-\mathrm{D}$, and Chen W-B. Thioredoxin is a novel diagnostic and prognostic marker in patients with ischemic stroke. Free Radic Biol Med 80: 129-135, 2015.

138. Radi R. Peroxynitrite, a stealthy biological oxidant. J Biol Chem 288: 26464-26472, 2013.

139. Reynolds WF, Rhees J, Maciejewski D, Paladino T, Sieburg H, Maki RA, and Masliah E. Myeloperoxidase polymorphism is associated with gender specific risk for Alzheimer's disease. Exp Neurol 155: 31-41, 1999.

140. Roberts LJ, Fessel JP, and Davies SS. The biochemistry of the isoprostane, neuroprostane, and isofuran pathways of lipid peroxidation. Brain Pathol 15: 143-148, 2005.

141. Roberts LJ and Morrow JD. Products of the isoprostane pathway: unique bioactive compounds and markers of lipid peroxidation. Cell Mol Life Sci 59: 808-820, 2002.

142. Rojo AI, Rada P, Mendiola M, Ortega-Molina A, Wojdyla K, Rogowska-Wrzesinska A, Hardisson D, Serrano M, and Cuadrado A. The PTEN/NRF2 axis promotes human carcinogenesis. Antioxid Redox Signal 21: 2498-2514, 2014.

143. Ryberg H, Söderling A-S, Davidsson P, Blennow K, Caidahl K, and Persson LI. Cerebrospinal fluid levels of free 3-nitrotyrosine are not elevated in the majority of patients with amyotrophic lateral sclerosis or Alzheimer's disease. Neurochem Int 45: 57-62, 2004.

144. Sabuncu T, Vural H, and Harma M. Oxidative stress in polycystic ovary syndrome and its contribution to the risk of cardiovascular disease. Clin Biochem 34: 407-413, 2001.

145. Sahaf B, Heydari K, Herzenberg LA, and Herzenberg LA. The extracellular microenvironment plays a key role in regulating the redox status of cell surface proteins in HIVinfected subjects. Arch Biochem Biophys 434: 26-32, 2005.

146. Salomon $\mathrm{R}$ and $\mathrm{Bi} \mathrm{W}$. Isolevuglandin adducts in disease. Antioxid Redox Signal 22: 1703-1718, 2015.

147. Salomon RG. Distinguishing levuglandins produced through the cyclooxygenase and isoprostane pathways. Chem Phys Lipids 134: 1-20, 2005.

148. Salomon RG. Levuglandins and isolevuglandins: stealthy toxins of oxidative injury. Antioxid Redox Signal 7: 185201, 2005.

149. Salomon RG, Jirousek MR, Ghosh S, and Sharma RB. Prostaglandin endoperoxides 21. Covalent binding of levuglandin E2 with proteins. Prostaglandins 34: 643-656, 1987.

150. Salomon RG and Miller DB. Levuglandins: isolation, characterization, and total synthesis of new secoprostanoid products from prostaglandin endoperoxides. $A d v$ Prostaglandin Thromboxane Leukot Res 15: 323-326, 1985.

151. Salzano S, Checconi P, Hanschmann E-M, Lillig CH, Bowler LD, Chan P, Vaudry D, Mengozzi M, Coppo L, Sacre S, Atkuri KR, Sahaf B, Herzenberg LA, Herzenberg LA, Mullen $\mathrm{L}$, and Ghezzi P. Linkage of inflammation and oxidative stress via release of glutathionylated peroxiredoxin-2, which acts as a danger signal. Proc Natl Acad Sci U S A 111: 12157-12162, 2014.
152. Schieber $M$ and Chandel NS. ROS function in redox signaling and oxidative stress. Curr Biol 24: R453-R462, 2014.

153. Schneider R, Raff U, Vornberger N, Schmidt M, Freund R, Reber M, Schramm L, Gambaryan S, Wanner C, Schmidt HHHW, and Galle J. L-arginine counteracts nitric oxide deficiency and improves the recovery phase of ischemic acute renal failure in rats. Kidney Int 64: 216225, 2003.

154. Schramm L, La M, Heidbreder E, Hecker M, Beckman JS, Lopau K, Zimmermann J, Rendl J, Reiners C, Winderl S, Wanner C, and Schmidt HHHW. L-arginine deficiency and supplementation in experimental acute renal failure and in human kidney transplantation. Kidney Int 61: 1423-1432, 2002.

155. Schulz E, Tsilimingas N, Rinze R, Reiter B, Wendt M, Oelze M, Woelken-Weckmüller S, Walter U, Reichenspurner H, Meinertz T, and Münzel T. Functional and biochemical analysis of endothelial (dys)function and $\mathrm{NO} /$ cGMP signaling in human blood vessels with and without nitroglycerin pretreatment. Circulation 105: 1170-1175, 2002.

156. Sies H. Glutathione and its role in cellular functions. Free Radic Biol Med 27: 916-921, 1999.

157. Sies H. Biochemistry of oxidative stress. Angewandte Chemie 25: 1058-1071, 1986.

158. Sies H. Oxidative stress: a concept in redox biology and medicine. Redox Biol 4: 180-183, 2015.

159. Simms CL, Hudson BH, Mosior JW, Rangwala AS, and Zaher HS. An active role for the ribosome in determining the fate of oxidized mRNA. Cell Rep 9: 1256-1264, 2014.

160. Souza JM, Choi I, Chen Q, Weisse M, Daikhin E, Yudkoff M, Obin M, Ara J, Horwitz J, and Ischiropoulos H. Proteolytic degradation of tyrosine nitrated proteins. Arch Biochem Biophys 380: 360-366, 2000.

161. Souza JM, Peluffo G, and Radi R. Protein tyrosine nitration-functional alteration or just a biomarker? Free Radic Biol Med 45: 357-366, 2008.

162. Spickett CM, Wiswedel I, Siems W, Zarkovic K, and Zarkovic N. Advances in methods for the determination of biologically relevant lipid peroxidation products. Free Radic Res 44: 1172-1202, 2010.

163. Spiteller G. Linoleic acid peroxidation-the dominant lipid peroxidation process in low density lipoprotein-and its relationship to chronic diseases. Chem Phys Lipids 95: 105-162, 1998.

164. Stadtman ER. Protein modification in aging. J Gerontol 43: B112-B120, 1988.

165. Steinberg D, Parthasarathy S, Carew TE, Khoo JC, and Witztum JL. Beyond cholesterol. Modifications of lowdensity lipoprotein that increase its atherogenicity. $N$ Engl J Med 320: 915-924, 1989.

166. Stocker R and Keaney JF. Role of oxidative modifications in atherosclerosis. Physiol Rev 84: 1381-1478, 2004.

167. Sultana R, Poon HF, Cai J, Pierce WM, Merchant M, Klein JB, Markesbery WR, and Butterfield DA. Identification of nitrated proteins in Alzheimer's disease brain using a redox proteomics approach. Neurobiol Dis 22: 7687, 2006.

168. Szabó-Taylor KÉ, Eggleton P, Turner CAL, Faro MLL, Tarr JM, Tóth S, Whiteman M, Haigh RC, Littlechild JA, and Winyard PG. Lymphocytes from rheumatoid arthritis patients have elevated levels of intracellular peroxiredoxin 2 , and a greater frequency of cells with exofacial perox- 
iredoxin 2, compared with healthy human lymphocytes. Int J Biochem Cell Biol 44: 1223-1231, 2012.

169. Takahashi M, Hoshino H, Kushida K, Kawana K, and Inoue $\mathrm{T}$. Direct quantification of pentosidine in urine and serum by HPLC with column switching. Clin Chem 42: 1439-1444, 1996.

170. Tanaka M, Chock PB, and Stadtman ER. Oxidized messenger RNA induces translation errors. Proc Natl Acad Sci U S A 104: 66-71, 2007.

171. Teerlink T, Luo Z, Palm F, and Wilcox CS. Cellular ADMA: regulation and action. Pharmacol Res 60: 448460, 2009.

172. Thome J, Münch G, Müller R, Schinzel R, Kornhuber J, Blum-Degen D, Sitzmann L, Rösler M, Heidland A, and Riederer P. Advanced glycation endproducts-associated parameters in the peripheral blood of patients with Alzheimer's disease. Life Sci 59: 679-685, 1996.

173. Thukkani AK, McHowat J, Hsu F-F, Brennan M-L, Hazen SL, and Ford DA. Identification of alpha-chloro fatty aldehydes and unsaturated lysophosphatidylcholine molecular species in human atherosclerotic lesions. Circulation 108: 3128-3133, 2003.

174. Totan Y, Yağci R, Bardak Y, Ozyurt H, Kendir F, Yilmaz G, Sahin S, and Sahin Tiğ U. Oxidative macromolecular damage in age-related macular degeneration. Curr Eye Res 34: 1089-1093, 2009.

175. Trpkovic A, Resanovic I, Stanimirovic J, Radak D, Mousa SA, Cenic-Milosevic D, Jevremovic D, and Isenovic ER. Oxidized low-density lipoprotein as a biomarker of cardiovascular diseases. Crit Rev Clin Lab Sci52: 70-85, 2015.

176. Tsikas D and Duncan MW. Mass spectrometry and 3nitrotyrosine: strategies, controversies, and our current perspective. Mass Spectrom Rev 33: 237-276, 2014.

177. Tsimikas S. Measures of oxidative stress. Clin Lab Med 26: 571-590, v-vi, 2006.

178. Tsimikas S, Lau HK, Han K-R, Shortal B, Miller ER, Segev A, Curtiss LK, Witztum JL, and Strauss BH. Percutaneous coronary intervention results in acute increases in oxidized phospholipids and lipoprotein(a): short-term and long-term immunologic responses to oxidized lowdensity lipoprotein. Circulation 109: 3164-3170, 2004.

179. Uchida K, Itakura K, Kawakishi S, Hiai H, Toyokuni S, and Stadtman ER. Characterization of epitopes recognized by 4-hydroxy-2-nonenal specific antibodies. Arch Biochem Biophys 324: 241-248, 1995.

180. Vadseth C, Souza JM, Thomson L, Seagraves A, Nagaswami C, Scheiner T, Torbet J, Vilaire G, Bennett JS, Murciano J-C, Muzykantov V, Penn MS, Hazen SL, Weisel JW, and Ischiropoulos H. Pro-thrombotic state induced by post-translational modification of fibrinogen by reactive nitrogen species. J Biol Chem 279: 88208826, 2004.

181. Valko M, Leibfritz D, Moncol J, Cronin MTD, Mazur M, and Telser J. Free radicals and antioxidants in normal physiological functions and human disease. Int J Biochem Cell Biol 39: 44-84, 2007.

182. Vallance P, Leone A, Calver A, Collier J, and Moncada S. Endogenous dimethylarginine as an inhibitor of nitric oxide synthesis. J Cardiovasc Pharmacol 20 Suppl 12: S60-S62, 1992.

183. van der Vliet A, Eiserich JP, Halliwell B, and Cross CE. Formation of reactive nitrogen species during peroxidasecatalyzed oxidation of nitrite. A potential additional mechanism of nitric oxide-dependent toxicity. $J$ Biol Chem 272: 7617-7625, 1997.

184. Vita JA, Brennan M-L, Gokce N, Mann SA, Goormastic M, Shishehbor MH, Penn MS, Keaney JF, and Hazen SL. Serum myeloperoxidase levels independently predict endothelial dysfunction in humans. Circulation 110: 11341139, 2004

185. Wacker BK, Albert CJ, Ford BA, and Ford DA. Strategies for the analysis of chlorinated lipids in biological systems. Free Radic Biol Med 59: 92-99, 2013.

186. Waeg G, Dimsity G, and Esterbauer H. Monoclonal antibodies for detection of 4-hydroxynonenal modified proteins. Free Radic Res 25: 149-159, 1996.

187. Wakita C, Honda K, Shibata T, Akagawa M, and Uchida $\mathrm{K}$. A method for detection of 4-hydroxy-2-nonenal adducts in proteins. Free Radic Biol Med 51: 1-4, 2011.

188. Wayenberg J-L, Ransy V, Vermeylen D, Damis E, and Bottari SP. Nitrated plasma albumin as a marker of nitrative stress and neonatal encephalopathy in perinatal asphyxia. Free Radic Biol Med 47: 975-982, 2009.

189. Weimann A, Belling D, and Poulsen HE. Measurement of 8-oxo-2"-deoxyguanosine and 8-oxo-2-"deoxyadenosine in DNA and human urine by high performance liquid chromatography-electrospray tandem mass spectrometry. Free Radic Biol Med 30: 757-764, 2001.

190. Weimann A, Belling D, and Poulsen HE. Quantification of 8-oxo-guanine and guanine as the nucleobase, nucleoside and deoxynucleoside forms in human urine by highperformance liquid chromatography-electrospray tandem mass spectrometry. Nucleic Acids Res 30: E7, 2002.

191. Weimann A, Broedbaek K, Henriksen T, Stovgaard ES, and Poulsen HE. Assays for urinary biomarkers of oxidatively damaged nucleic acids. Free Radic Res 46: 531$540,2012$.

192. WHO. Biomarkers in Risk assessment: Validity and Validation. Geneva: WHO, 2001.

193. Witko-Sarsat V, Nguyen Khoa T, Jungers P, Drüeke T, and Descamps-Latscha B. Advanced oxidation protein products: oxidative stress markers and mediators of inflammation in uremia. Adv Nephrol Necker Hosp 28: 321341, 1998.

194. Wu T, Willett WC, Rifai N, Shai I, Manson JE, and Rimm EB. Is plasma oxidized low-density lipoprotein, measured with the widely used antibody 4E6, an independent predictor of coronary heart disease among U.S. men and women? J Am Coll Cardiol 48: 973-979, 2006.

195. Yamakura F, Taka H, Fujimura T, and Murayama K. Inactivation of human manganese-superoxide dismutase by peroxynitrite is caused by exclusive nitration of tyrosine 34 to 3-nitrotyrosine. J Biol Chem 273: 14085-14089, 1998.

196. Yang H, Wang W, Zhang Y, Zhao J, Lin E, Gao J, and He $\mathrm{J}$. The role of NF-E2-related factor 2 in predicting chemoresistance and prognosis in advanced non-small-cell lung cancer. Clin Lung Cancer 12: 166-171, 2011.

197. Yi D, Ingelse BA, Duncan MW, and Smythe GA. Quantification of 3-nitrotyrosine in biological tissues and fluids: generating valid results by eliminating artifactual formation. J Am Soc Mass Spectrom 11: 578-586, 2000.

198. Yin H and Porter NA. New insights regarding the autoxidation of polyunsaturated fatty acids. Antioxid Redox Signal 7: 170-184, 2005.

199. Yodoi J and Maeda M. Discovery of ATL: an odyssey in restrospect. Int J Hematol 94: 423-428, 2011. 
200. Zarkovic N. 4-Hydroxynonenal as a bioactive marker of pathophysiological processes. Mol Aspects Med 24: 281291, 2003.

Address correspondence to: Prof. Pietro Ghezzi Brighton \& Sussex Medical School

Falmer

Brighton

United Kingdom

E-mail: p.ghezzi@bsms.ac.uk

Date of first submission to ARS Central, March 19, 2015; date of final revised submission, August 25, 2015; date of acceptance, September 8, 2015.

\section{Abbreviations Used}

3-Cl-Tyr $=3$-chlorotyrosine

4-HNE $=$ trans-4-hydroxy-2-nonenal

8oxodG $=7,8$-dihydro-8-oxo- 2 '-deoxyguanosine

8oxoGuo $=7,8$-dihydro-8-oxo-guanosine

$\mathrm{AA}=$ arachidonic acid

ACS $=$ acute coronary syndrome

$\mathrm{AD}=$ Alzheimer's disease

ADMA $=$ asymmetric dimethyl L-arginine

AGEs $=$ advanced glycation end products

AIDS $=$ acquired immunodeficiency syndrome

$\mathrm{AMI}=$ acute myocardial infarction

$\mathrm{ASD}=$ autism spectrum disorders

$\mathrm{AT} 1 \mathrm{R}=$ angiotensin receptor 1

$\mathrm{BMI}=$ body - mass index

$\mathrm{CAD}=$ coronary artery disease

$\mathrm{CBS}=$ cardiac biomarker score

$\mathrm{CPB}=$ cardiopulmonary bypass

cGMP $=$ cyclic guanosine monophosphate

$\mathrm{CHD}=$ coronary heart disease

$\mathrm{CKD}=$ chronic kidney disease;

$\mathrm{CML}=$ carboxymethyl lysine

$\mathrm{CO}_{2}=$ carbon dioxide

$\mathrm{CRF}=$ chronic renal failure

$\mathrm{CRP}=\mathrm{C}$-reactive protein

$\mathrm{CSF}=$ cerebrospinal fluid

$\mathrm{CVD}=$ cardiovascular disease

DDAH $=N^{G}-N^{G}$-dimethylarginine dimethylaminohydrolase

$\mathrm{DNP}=2$,4-dinitrophenylhydrazine

eNOS $=$ endothelial NOS

$\mathrm{FC}=$ flow cytometry

$\mathrm{GC}=$ gas chromatography

Grx $=$ glutaredoxin

$\mathrm{GSH}=$ glutathione

GSSG $=$ oxidized glutathione

$\mathrm{H}_{2} \mathrm{O}_{2}=$ hydrogen peroxide

$\mathrm{HCC}=$ hepatocellular carcinoma

$\mathrm{HDL}=$ high-density lipoprotein

$\mathrm{HIV}=$ human immunodeficiency virus
$\mathrm{HOCl}=$ hypochlorous acid

HPLC $=$ high-performance liquid chromatography

$\mathrm{IHC}=$ immunohistochemistry

IL-6 = interleukin-6

IS $=$ ischemic stroke

IsoLG $=$ isolevuglandins

IsoPs $=$ isoprostanes

$\mathrm{LC}=$ liquid chromatography

$\mathrm{LDL}=$ low-density lipoprotein

$\mathrm{MACE}=$ major adverse cardiac events

$\mathrm{MCI}=$ myocardial infarction

MDA $=$ malondialdehyde

$\mathrm{MI}=$ myocardial infarct

$\mathrm{MPO}=$ myeloperoxidase

$\mathrm{MS}=$ mass spectrometry

$\mathrm{NO}=$ nitric oxide

NOS $=$ NO synthase

$\mathrm{NOX}=\mathrm{NADPH}$ oxidase

$\mathrm{NRF} 2=$ nuclear factor (erythroid-derived 2)-like 2

$\mathrm{NRP}=$ nonradical product

$\mathrm{OA}=$ osteoarthritis

$\mathrm{ONOOCO}_{2}=$ nitrosoperoxocarbonate

oxLDL $=$ oxidized LDL

OxRed $=$ oxidoreductases

$\mathrm{PAD}=$ peripheral artery disease

$\mathrm{PC}=$ protein carbonyls

$\mathrm{PCI}=$ percutaneous coronary intervention

$\mathrm{PCOS}=$ polycystic ovary syndrome

$\mathrm{PCR}=$ polymerase chain reaction

$\mathrm{PDGF}=$ platelet-derived growth factor

$\mathrm{PSE}=$ post-stroke epilepsy

$\mathrm{P}-\mathrm{VASP}=$ phosphorylated vasodilator-stimulated phosphoprotein

Pr-SS-G = protein mixed disulfide

PrCarb $=$ protein carbonyls

$\operatorname{Prx}=$ peroxiredoxin

PUFA $=$ polyunsaturated fatty acids

$\mathrm{qRT}-\mathrm{PCR}=$ quantitative real time polymerase chain reaction

$\mathrm{RA}=$ rheumatoid arthritis

$\mathrm{RBC}=$ red blood cell

$\mathrm{RNS}=$ reactive nitrogen species

ROS $=$ reactive oxygen species

$\mathrm{SAF}=$ skin autofluorescence

$\mathrm{sGC}=$ soluble guanylate cyclase

$\mathrm{SLE}=$ systemic lupus erythematosus

SODs $=$ superoxide dismutases

sRAGE $=$ secreted receptor for AGE

$\mathrm{T} 1 \mathrm{D}=$ type 1 diabetes

T2D = type 2 diabetes

TBARS $=$ thiobarbituric acid reactive substances

$\mathrm{TNF}=$ tumor necrosis factor

$\mathrm{TnT}=$ troponin $\mathrm{T}$

$\operatorname{Trx}=$ thioredoxin

Tyr- $\mathrm{NO}_{2}=$ nitrotyrosine

u-eNOS $=$ uncoupled eNOS

$\mathrm{UPLC}=$ ultra performance LC

$\mathrm{XDH}=$ xanthine dehydrogenase

$\mathrm{XO}=$ xanthine oxidase 